\title{
Biomarkers and inorganic proxies in the paleoenvironmental reconstruction of mires: The importance of landscape in Las Conchas (Asturias, Northern Spain) ${ }^{\text {it }}$
}

\author{
José E. Ortiz ${ }^{\mathrm{a}, *}$, Ángeles G. Borrego ${ }^{\mathrm{b}}$, José L.R. Gallego ${ }^{\mathrm{c}}$, Yolanda Sánchez-Palencia ${ }^{\mathrm{a}}$, Justyna Urbanczyk ${ }^{\mathrm{b}}$, \\ Trinidad Torres ${ }^{a}$, Laura Domingo ${ }^{\text {d,e,f }}$, Belén Estébanez ${ }^{g}$ \\ ${ }^{a}$ Biomolecular Stratigraphy Laboratory, E.T.S.I. Minas y Energía, Universidad Politécnica de Madrid, Madrid 28003, Spain \\ ${ }^{\mathrm{b}}$ Instituto Nacional del Carbón (INCAR-CSIC), Ap. 73, Oviedo 33080, Spain \\ ${ }^{\mathrm{C}}$ Environmental Biotechnology and Geochemistry Group, Campus de Mieres, Universidad de Oviedo, Mieres 33600, Spain \\ ${ }^{\mathrm{d}}$ Departamento de Geología Sedimentaria y Cambio Medioambiental, Instituto de Geociencias (CSIC-UCM), Madrid 28040, Spain \\ 'Departamento de Paleontología, Universidad Complutense de Madrid, Madrid 28040, Spain \\ ${ }^{\mathrm{f}}$ Earth and Planetary Sciences Department, University of California, Santa Cruz, CA 95064, USA \\ ${ }^{g}$ Facultad de Ciencias (Biología), Universidad Autónoma de Madrid, Campus de Cantoblanco, C/Darwin 2, 28049 Madrid, Spain
}

\begin{abstract}
A B S T R A C T
We determined the lipid distributions ( $n$-alkanes, $n$-alkan-2-ones, $n$-alkanoic acids), total organic carbon (TOC), total nitrogen (TN), Ca/Mg and ash content in Las Conchas mire, a $3.2 \mathrm{~m}$ deep bryophytedominated mire in Northern Spain covering 8000 cal yr BP. Bog conditions developed in the bottom $20 \mathrm{~cm}$ of the profile, and good preservation of organic matter (OM) was inferred from $n$-alkanoic acid distribution, with the exception of the uppermost $20 \mathrm{~cm}$ (last ca. $200 \mathrm{yr}$ ). Microbial synthesis of long chain saturated fatty acids from primary OM likely produced a dominance of short chain $n$-alkanoic acids with a bimodal distribution, as well as the lack of correspondence between the $n$-alkane and $n$-alkanoic acid profiles in the upper $20 \mathrm{~cm}$. This was accompanied by an increase in ash content, a decrease in TOC and variation in $n$-alkane ratios, thereby suggesting significant changes in the mire, namely drainage and transformation to a meadow, in the last ca. $200 \mathrm{yr}$. The distribution of $n$-alkan-2-ones indicated an increase in bacterial source from the bottom of the record to $94 \mathrm{~cm}$, whereas their distribution in the upper part could be attributed mainly to plant input and/or the microbial oxidation of $n$-alkanes. The different $n$-alkane proxies showed variations, which we interpreted in terms of changes in vegetation (Sphagnum vs. non-Sphagnum dominated phases) during the last $8000 \mathrm{cal}$ yr BP. $\mathrm{C}_{23}$ was the most abundant homolog throughout most of the record, thereby suggesting dominant humid conditions alternating with short drier phases. However, such humid conditions were not linked to paleoclimatic variation but rather to geomorphological characteristics: Las Conchas mire, at the base of the Cuera Range, receives continuous runoff-even during drier periods-which is not necessarily accompanied by additional mineral input to peat, producing the development of Sphagnum moss typical of waterlogged ecotopes and damp habitats. Thus, although geochemical proxies indicated an ombrotrophic regime in the mire, geomorphological characteristics may make a considerable contribution to environmental conditions.
\end{abstract}

\section{Introduction}

Mires contain valuable lipid records that can be used to reconstruct past climate evolution, even during the Holocene when relatively subtle climate shifts occurred. Research into the behavior

\footnotetext{
This study was presented at the 27th IMOG Meeting, Prague, Czech Republic, September 13th-18th, 2015.

* Corresponding author. Tel.: +3491336 6970 .

E-mail address: joseeugenio.ortiz@upm.es (J.E. Ortiz).
}

and nature of mires has provided insight into paleoenvironmental evolution, global climate change and the impact of human activity.

Northwestern Spain contains a number of bogs that have developed on high plains relatively close to the coast (within $4 \mathrm{~km}$ ). Organic geochemical studies of them have allowed reconstruction of humid and dry periods over the Holocene (Ortiz et al., 2010; López-Días et al., 2010a, 2013a). Of particular interest is that the mires in the region are located on the southern edge of the European Atlantic climate region and provide information on the paleoenvironmental evolution at the boundary with the 
Mediterranean region. Located in the area, Las Conchas mire has particular geomorphological conditions that make it of interest for the study of the lipid content to infer paleoenvironmental conditions, thereby allowing comparison with other records for this region.

Biomarkers such as n-alkanes occur widely in peat samples from mires. The $n$-alkane content and distribution have been used to discriminate between Sphagnum (moss) vs. Erica (heather) input and in turn to reconstruct paleoenvironmental conditions linked to humid or drier climatic phases (Nott et al., 2000; Pancost et al., 2002; McClymont et al., 2005; Nichols et al., 2006; Ortiz et al., 2010). n-Alkan-2-ones also occur in peat (Morrison and Bick, 1967; Lehtonen and Ketola, 1990; Xie et al., 2004; Nichols and Huang, 2007; Zheng et al., 2007; Ortiz et al., 2010; López-Días et al., 2013b). They may have diverse origins, including direct input from plants (Arpino et al., 1970; Volkman et al., 1981), microbial oxidation of $n$-alkanes (Cranwell et al., 1987; Amblès et al., 1993; Jaffé et al., 1993, 1996; van Bergen et al., 1998), microbial $\beta$-oxidation and decarboxylation of fatty acids (FAs; Volkman et al., 1983; Chaffee et al., 1986; de Leeuw, 1986; Quénéa et al., 2004) and bacterial material (López-Días et al., 2013b).

Like aliphatic hydrocarbons, $n$-alkanoic acids derive from plants and microorganisms, and their distribution can be used to distinguish between land plant and algal sources. However, selective degradation and diagenesis, including microbial degradation and synthesis of other compounds, commonly overprint $n$-alkanoic acid distributions (Cranwell, 1974, 1976; Kawamura et al., 1987; Haddad et al., 1992; Ho and Meyers, 1994).

The characteristics of mires condition the information provided by biomarkers in paleoenvironmental reconstruction. Ombrotrophic bogs receive water exclusively from rainfall and are characterized by the accumulation of peat in a raised mass over the groundwater table. In contrast, minerotrophic fens also receive water from surface water and groundwater, and are influenced by the mineralogy of the substrate (Shotyk, 1996a), thus limiting their utility for the interpretation of climatic conditions. Assessing the geochemical status of a peatland provides information on its trophic status, the likely source of nutrients and other inorganic elements (atmospheric vs. non-atmospheric), and their subsequent fate within the deposit (Weiss et al., 2002).

Bogs can be geochemically overprinted significantly by groundwater or upward diffusion of dissolved elements released by mineral weathering (Hill and Siegel, 1991; Shotyk, 1996a; Weiss et al., 1997). To identify the presence and extent of an ombrotrophic zone, the $\mathrm{Ca} / \mathrm{Mg}$ ratio in the peat can be compared with that of local rainwater (Shotyk, 1996b; Steinman and Shotyk, 1997; Weiss et al., 1997). Traditionally, low ash content ( $<5 \%)$ has also been used for the characterization of ombrotrophic mires (Naucke, 1990; Steinman and Shotyk, 1997; Weiss et al., 2002), although higher concentrations have been observed in some ombrotrophic bogs as a result of other processes.

Here we sought to contrast the information provided by organic geochemistry (TOC, atomic $C / N$ ratio and lipid proxies) and the inorganic fraction (ash content, selected trace elements), together with geomorphological characteristics, to reconstruct paleoenvironmental conditions in mires. For this purpose we selected the record of Las Conchas mire, in the northwestern part of the Iberian Peninsula, which covers the last ca. 8000 cal yr BP. The ash content, $C$ and $N$ content of $O M$, and biomarkers, mainly $n$-alkanes, $n$-alkan-2-ones and $n$ alkanoic acids, were studied at high resolution to address OM sources and diagenetic processes. Also, the geochemistry of the mire water was compared with that of rainwater, springs and rivers.

\section{Geographical and geological setting}

Covering ca. $100,000 \mathrm{~m}^{2}$, Las Conchas mire is located (UTM 30 $360.627,4.803 .642 ; 363 \mathrm{~m}$ ) in the Eastern part (Llanes county) of the province of Asturias (N. Spain; Fig. 1). It has a maximum depth of $3.2 \mathrm{~m}$ and lies on the Ordovician quartzites of the Barrios Formation, at the top of an ancient marine abrasion platform (Martinez García, 1980)-a formation that is typical in this area. This platform laterally leans on the Cuera Range (Fig. 1), which is made up of karstified carboniferous limestones (Barcaliente, Valdeteja and Cuera formations).

This region has an Atlantic type climate, characterized by humid temperate winters and occasional droughts in the summer, with annual mean temperature of $13.1^{\circ} \mathrm{C}$ and annual mean precipitation $1136 \mathrm{~mm} / \mathrm{yr}$ (Rivas-Martínez and Rivas y Sáenz, 2015).

The current vegetation in the mire includes mainly species of Sphagnum (Sphagnum denticulatum being especially abundant) and Gramineae. However, other types of moss (Calliergonella cuspidata, Polytrichum commune, Campylopus flexuosus, Aulacomnium palustre, Kindbergia praelonga) and vascular plants, including the gorse Ulex europaeus, and the rush Juncus effusus, among others, can be found. The presence of the heathers Erica mackaiana, endemic to the North of Spain, and Erica tetralix is also common. Of note, Las Conchas mire has a central area which has been turned into a meadow for livestock grazing.

\section{Material and methods}

\subsection{Peat coring and sample preparation}

A $3.2 \mathrm{~m}$ core was drilled in the central part of Las Conchas mire with a manual probe $(5 \mathrm{~cm}$ diameter). The core was split in half longitudinally, photographed and described, and then sliced into portions $2 \mathrm{~cm}$ thick. Samples were freeze dried at $-18^{\circ} \mathrm{C}$ by means of a lyophilizer (Moore and Hilbert, 1992; Esterle and Ferm, 1994) before analysis to prevent alteration of the OM.

The record consisted of bryophytic, spongy, reddish and brownish peat, with clearly recognizable plant remains. It was darker towards the bottom, except for the last few $\mathrm{cm}$, which consisted of gray and light colored silt (Fig. 2). We refer to the horizons of the core by their depth (in $\mathrm{cm}$ ) from top to bottom (e.g. level LC230 is at $230 \mathrm{~cm}$ ).

Samples were taken for radiocarbon dating, determination of ash content, total organic $\mathrm{C}$ (TOC) and total $\mathrm{N}$ (TN) contents, and lipid and trace element analysis. Additionally, living terrestrial plants were selected for lipid analysis.

\subsection{Living plants}

Living plants from the mire, including various mosses and stems from vascular plants (Table 2), were selected for lipid analysis. In order to avoid degradation and contamination, they were frozen immediately after collection. Prior to analysis, they were washed and classified. The mosses, including Sphagnum, and grasses (Gramineae) comprise the main plant inputs to the mire at present, although other plants, including Ericaceae, also contribute to peat composition. We selected the plant specimens on the basis of their current abundance in the mire ( $S$. denticulatum, Gramineae, J. effusus and U. europaeus) and diversity (nonSphagnum mosses). For other species of Las Conchas, we consider the results of Ortiz et al. (2011) from the neighboring peat bog of Roñanzas (only $1 \mathrm{~km}$ from Las Conchas, Fig. 1).

\subsection{Radiocarbon dating}

Peat samples (12) from various depths (Table 1) were sent to the "Centro Nacional de Aceleradores" (C.S.I.C., Seville, Spain) for radiocarbon dating. Samples were pre-treated with dilute $\mathrm{HCl}$ to remove carbonate and with $\mathrm{NaOH}$ to remove secondary organic 

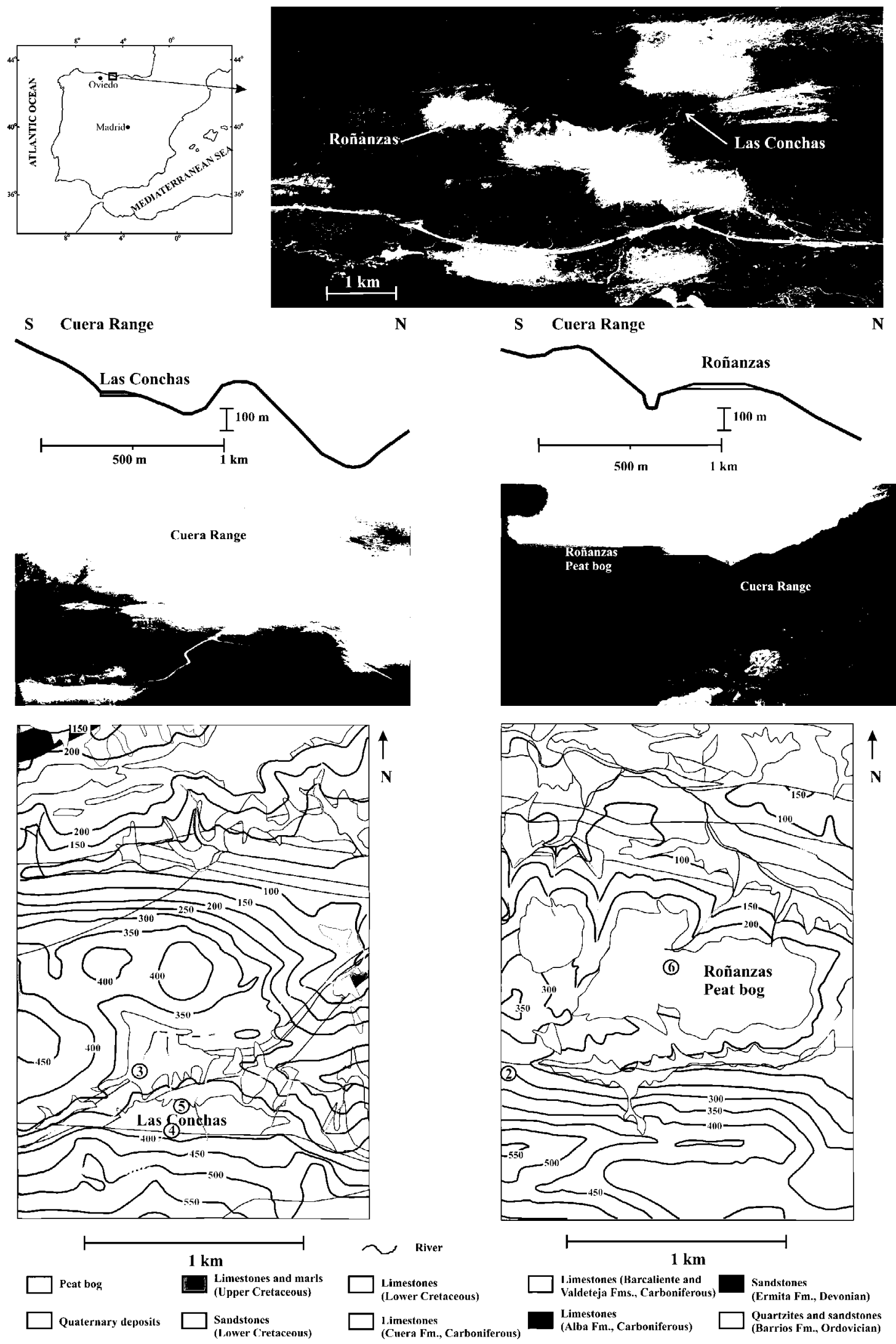

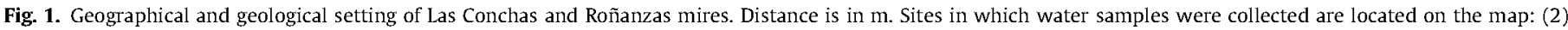
Spring in Cuera Range, (3) Tornu river, (4) contact zone between Las Conchas mire and the Cuera Range, (5) Las Conchas mire, (6) Roñanzas peat bog. 


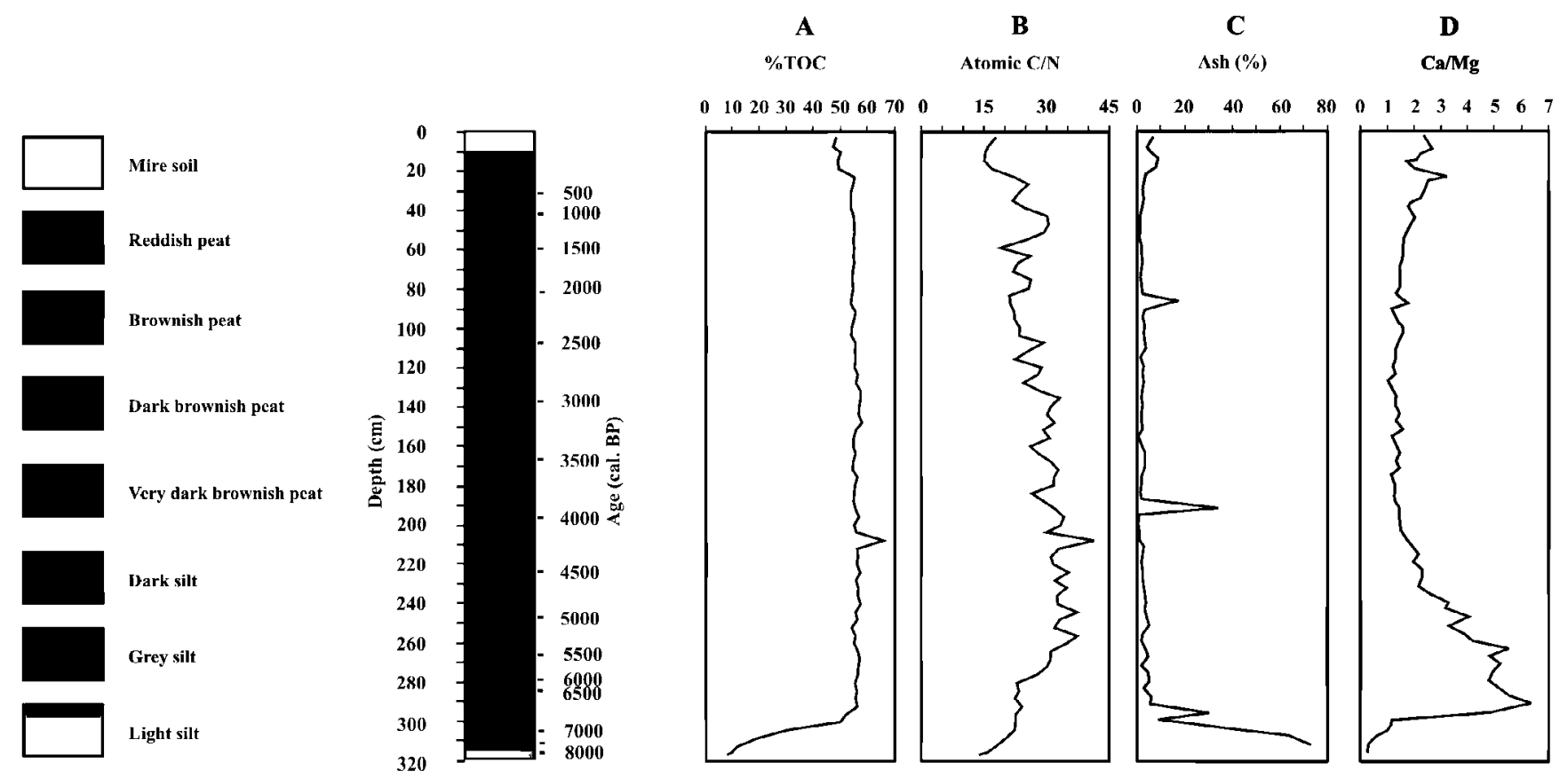

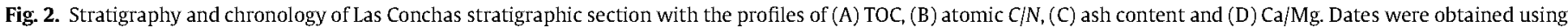
the radiocarbon method.

Table 1

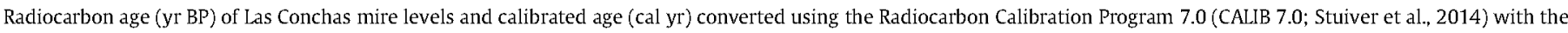
calibration dataset IntCal13 (Reimer et al., 2013).

\begin{tabular}{|c|c|c|c|c|c|}
\hline Sample & No. & Depth (cm) & $\delta^{13} \mathrm{C}(\mathrm{V}-\mathrm{PDB})$ & Conventional age BP & Calibrated BP \\
\hline LC-14.2 & CNA1444 & 14.2 & -28.98 & $105 \pm 40$ & $141 \pm 40$ \\
\hline LC-23.8 & CNA1445 & 23.8 & -28.14 & $1020 \pm 45$ & $216 \pm 45$ \\
\hline LC-37.8 & CNA1446 & 37.8 & -33.25 & $1445 \pm 40$ & $1346.5 \pm 40$ \\
\hline LC-72.4 & CNA1447 & 72.4 & -31.74 & $1925 \pm 50$ & $1861.5 \pm 50$ \\
\hline LC-118.4 & CNA1448 & 118.4 & -24.28 & $2980 \pm 45$ & $3136.5 \pm 45$ \\
\hline LC-186.4 & CNA1449 & 186.4 & -24.32 & $4010 \pm 40$ & $4496.5 \pm 40$ \\
\hline LC-220.4 & CNA1450 & 220.4 & -36.19 & $3760 \pm 60$ & $4130 \pm 60$ \\
\hline LC-244.4 & CNA1451 & 244.4 & -30.57 & $4260 \pm 45$ & $4849.5 \pm 45$ \\
\hline LC-278.4 & CNA1452 & 278.4 & -23.73 & $4805 \pm 45$ & $5537 \pm 45$ \\
\hline LC-294.4 & CNA1453 & 294.4 & -27.84 & $5375 \pm 45$ & $6143.5 \pm 45$ \\
\hline LC-312.4 & CNA1454 & 312.4 & -25.65 & $6880 \pm 70$ & $7755 \pm 70$ \\
\hline LC-314.4 & CNA1455 & 314.4 & -20.57 & $6740 \pm 50$ & $7616.5 \pm 50$ \\
\hline
\end{tabular}

acids. Finally, they were acid rinsed to neutralize the solution prior to drying. $C$ in the samples was reduced to graphite $(100 \%)$, which was examined for ${ }^{14} \mathrm{C}$ content with an accelerator mass spectrometer, and the radiocarbon age was calculated and calibrated using the CALIB 7.0 program (Stuiver et al., 2014) with the INTCAL13 calibration curve (Reimer et al., 2013). All age values are in calibrated years BP (cal BP).

\subsection{Ash content}

A total of 78 samples recovered at $2 \mathrm{~cm}$ intervals of ca. $0.5-1 \mathrm{~g}$ peat was selected to determine ash content. Samples were placed in a porcelain crucible, dried at $110^{\circ} \mathrm{C}$ for $3 \mathrm{~h}$ and weighed. They were then heated at $900^{\circ} \mathrm{C}$ in a muffle furnace for $3 \mathrm{~h}$ and weighed. The ash content (\% dry wt) is the weight of the sample heated at $900^{\circ} \mathrm{C}$ divided by the dry weight after heating at $110^{\circ} \mathrm{C}$.

\subsection{TOC, TN}

The same 78 samples were selected for $\mathrm{C}, \mathrm{H}$ and $\mathrm{N}$ analysis, performed with a LECO CHN apparatus after removing carbonate via addition of $\mathrm{HCl}$.

\subsection{Lipid extraction and analysis (biomarker analysis)}

Another set of 78 samples from the core was used. Between 0.2 and $0.7 \mathrm{~g}$ dried sample were ground, and biomarkers extracted using accelerated solvent extraction (Dionex ASE 200). Free lipids were extracted with dichloromethane (DCM)/MeOH (2:1) at 1500 psi and $175^{\circ} \mathrm{C}$. The heating phase was $8 \mathrm{~min}$ and the static extraction time $5 \mathrm{~min}$. Living plants were prepared following the same procedure.

The extract was concentrated using rotary evaporation. Prior to analysis using gas chromatography-mass spectrometry (GC-MS), samples were methylated with trimethylsilyldiazomethane and silylated with a mixture of $\mathrm{N}, \mathrm{O}$-bis(trimethylsilyl)trifluoroaceta mide (BSTFA) and pyridine at $70^{\circ} \mathrm{C}$ for $2 \mathrm{~h}$. Samples were injected into an HP 6890 gas chromatograph equipped with a selective mass detector (HP 5973) and an ATM-5 column ( $25 \mathrm{~m} \times 0.25 \mathrm{~mm}$; $0.20 \mu \mathrm{m})$. He was the carrier gas and decafluorobiphenyl an internal standard. The oven temperature was programmed from 60 to $300^{\circ} \mathrm{C}$ (held $20 \mathrm{~min}$ ) at $6{ }^{\circ} \mathrm{C} / \mathrm{min}$, and the injector was maintained at $275^{\circ} \mathrm{C}$. Components were identified with the Data Analysis programme and the Wiley Library. Although other compounds were identified in the samples, we focused this study on $n$-alkanes and 
Table 2

Concentration of $n$-alkanes in plants from Las Conchas mite (highest values in bold).

\begin{tabular}{|c|c|c|c|c|c|c|c|c|c|c|c|c|c|c|c|}
\hline \multirow[t]{2}{*}{ Species } & \multirow[t]{2}{*}{ Common name } & \multicolumn{14}{|c|}{ Alkane $C_{\text {no }}(\mu g / g$ dry plant matter $)$} \\
\hline & & 21 & 22 & 23 & 24 & 25 & 26 & 27 & 28 & 29 & 30 & 31 & 32 & 33 & Sum \\
\hline Ulex europaeus & Gorse & 1.05 & 0.33 & 0.49 & 0.31 & 4.14 & 1.29 & 9.97 & 4.86 & 25.14 & 0.92 & 19.60 & 0.00 & 0.00 & 68.10 \\
\hline Juncus effusus & Rush & 0.36 & 0.00 & 0.14 & 0.13 & 1.04 & 0.14 & 3.05 & 1.29 & 21.67 & 1.30 & 7.98 & 3.60 & 1.79 & 42.49 \\
\hline Gramineae 1 & Grass & 1.66 & 0.00 & 1.05 & 0.17 & 10.54 & 0.39 & 15.79 & 2.31 & 14.77 & 0.73 & 29.91 & 0.91 & 3.83 & 82.06 \\
\hline Gramineae 2 & Grass & 2.07 & 0.42 & 2.97 & 0.69 & 12.46 & 1.69 & 12.91 & 1.63 & 7.21 & 1.18 & 5.61 & 3.38 & 0.00 & 52.23 \\
\hline Calliergonella cuspidata & Moss & 1.14 & 0.64 & 0.30 & 0.81 & 4.67 & 0.60 & 14.49 & 0.84 & 7.68 & 0.48 & 6.90 & 0.00 & 0.00 & 38.55 \\
\hline Polytrichum commune & Moss & 1.66 & 0.40 & 0.39 & 1.03 & 5.19 & 0.70 & 3.19 & 1.14 & 6.99 & 0.76 & 3.31 & 0.00 & 0.00 & 24.76 \\
\hline Campylopus flexuosus & Moss & 0.00 & 1.21 & 2.72 & 0.85 & 9.10 & 1.42 & 12.32 & 1.96 & 13.73 & 1.87 & 45.89 & 2.76 & 0.00 & 93.83 \\
\hline Sphagmum denticulatum & Moss & 0.00 & 1.89 & 36.40 & 1.05 & 20.69 & 1.07 & 6.68 & 1.39 & 3.37 & 0.69 & 8.65 & 0.52 & 0.00 & 82.41 \\
\hline Aulacomnium palustre & Moss & 0.00 & 0.97 & 1.34 & 1.69 & 11.50 & 1.73 & 29.33 & 3.00 & 23.38 & 1.55 & 30.03 & 1.12 & 0.00 & 105.66 \\
\hline Kindbergia praelonga & Moss & 0.00 & 0.00 & 0.99 & 1.93 & 10.70 & 2.86 & 21.71 & 2.19 & 9.60 & 1.47 & 28.69 & 1.82 & 9.76 & 91.72 \\
\hline
\end{tabular}

$n$-alkanoic acids; $n$-alkane distributions were obtained from the $m /$ $z 57$ chromatograms (base peak), the $n$-alkan-2-ones from $m / z 59$, and the $n$-alkanoic acids from $m / z 74$.

\subsection{Multi-element inorganic analysis}

The same set of 78 representative samples was dried at $40^{\circ} \mathrm{C}$ in order to minimize loss of volatile elements ( $\mathrm{Hg}$, As), then softly hand milled and homogenized with an agate mortar and pestle, mechanically split (riffle) to obtain a representative sample, and pulverized again to at least $85 \%$ passing 200 mesh $(75 \mu \mathrm{m})$. All utensils were thoroughly cleaned with EtOH between samples.

The samples were analyzed at Activation Laboratories Ltd. (Actlabs; Ancaster, Ontario, Canada). Actlabs is an ISO (International Organization for Standardization) 17025 (Lab 266) and NELAP (National Environmental Laboratory Accreditation Program; Lab E87979) accredited lab for specific registered tests. For QA/QC (quality assurance/quality control), Actlabs systematically inserts standards, duplicates and blanks into every sample batch. In this case, analysis included data on eight compositionally different standards with well defined element concentrations. In addition, duplicate samples were routinely analyzed. In brief, an aliquot $(1 \mathrm{~g})$ of sample in an open Teflon reactor was subjected to addition of a mixture of $\mathrm{HNO}_{3}, \mathrm{HClO}_{4}, \mathrm{HCl}$ and $\mathrm{HF}$. This results in "near total" digestion to achieve the greatest degree of sample dissolution without fusing the sample.

After evaporation to dryness, the residue was dissolved in $\mathrm{HCl}$ and diluted with distilled water. The solution was analyzed by way of inductively coupled plasma-mass MS (ICP-MS).

\subsection{Water characterization}

Composite water samples were collected during summer from rainfall, a spring located in the Cuera Range, a river (Tornu), the surface of Las Conchas mire (at the contact with Cuera Range and at the other edge of the mire) and Ronanzas mire (Fig. 1), without disturbing the sediment. Laboratory-cleaned sample bottles were used for this purpose. The $\mathrm{pH}$ and conductivity were monitored using a BASIC $20 \mathrm{pH}$ meter and an EC Meter BASIC 30+, respectively [both from Crison (Barcelona, Spain)]. The main cations and anions were determined using ion chromatography (Metrohm 883 Basic IC Plus). TOC was measured with a TOC-V $\mathrm{V}_{\mathrm{CSH}}$ Analyzer (Shimadzu, Kyoto, Japan).

\section{Results}

\subsection{Chronology}

The age values are shown in Table 1 . An age-depth model was constructed by means of a 3 rd order polynomic interpolation
(Fig. 3), which was the one that best fit (highest correlation coefficient), taking into account maximum probability intervals at a $2 \sigma$ range, which is considered a robust statistical value (Telford et al., 2004). For the chronological model, the sample taken at $186.4 \mathrm{~cm}$ was excluded because of the high mineral content (35\%) observed in nearby levels (Fig. 2C), which may indicate the reworking of OM. This approach allowed calculation of the age of undated intermediate horizons using the chronological scale in Fig. 2. The results indicate that the core covered the last ca. $8000 \mathrm{calyr} \mathrm{BP}$. The accumulation rate was $0.5 \mathrm{~mm} / \mathrm{yr}$ from 6500 to $500 \mathrm{cal}$ yr BP, coinciding with other Asturian mires (cf. López-Días et al., 2013a). However, the sedimentation rate was lower in the uppermost $25 \mathrm{~cm}$, probably due to gaps that were not possible to detect, and at the bottom $(315-290 \mathrm{~cm})$, because of compaction.

\subsection{Ash content (\% dry wt)}

The lithological description of the profile and ash content, the latter reflecting the mineral fraction of the record, is shown in Fig. 2C. In general, the ash content was low $(<3 \%)$, with the exception of the bottom $(312-294 \mathrm{~cm})$, which was characterized by an interval of light gray silt with high mineral matter content (ash $>10 \%$ ). Likewise, in the upper $20 \mathrm{~cm}$, the ash content was $>5 \%$, reaching values as high $9.6 \%$. Of note, some levels $(190 \mathrm{~cm}$,

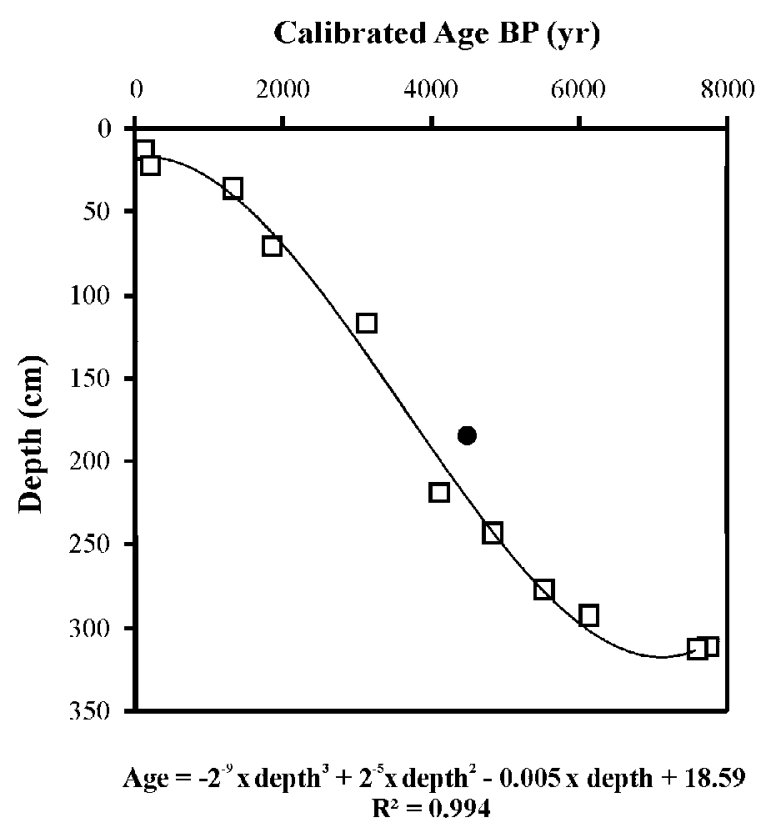

Fig. 3. Age-depth relationship for Las Conchas mire core. Dates (Table 1) were obtained through the radiocarbon method. 
$86 \mathrm{~cm}$ ) had values $>15 \%$, although they seemed to be analytical errors as these maxima were not paralleled by minima in the TOC record.

\subsection{TOC and $C / N$}

The concentration of TOC was between ca. $7 \%$ and $30 \%$ at the bottom (320-300 cm) and increased sharply upwards to between $53 \%$ and $58 \%$ (Fig. 2A). A high carbon concentration (66\%) at $207 \mathrm{~cm}$ probably reflected a contribution from charcoal. TOC decreased in the upper $20 \mathrm{~cm}$, with values ranging from $47 \%$ to $49 \%$. Atomic $C / N$ values in the mire were between 15 and 20 in the interval $3.16-3.06 \mathrm{~m}$ and in the upper $20 \mathrm{~cm}$ (Fig. 2B). In the rest of the core, values exceeded 25 , reaching a maximum at $206 \mathrm{~cm}(48.2)$

\subsection{Lipids}

The distributions of $n$-alkanes, $n$-alkan-2-ones and $n$-alkanoic acids are shown in Figs. 4 and 5.

\subsection{1. n-Alkanes}

Typical chromatograms from selected samples are shown in Fig. 4. All the samples showed a predominance of odd $n$-alkanes, with a distribution ranging mainly from $C_{17}$ to $C_{33}$ or $C_{35}$, and a bimodal distribution maximizing at either $C_{23}$ (Fig. $4 \mathrm{~A}$ ) or $C_{31}$ (Fig. 4B).

The values of various indices, namely the predominant $n$-alkane chain, average chain length (ACL), aquatic macrophytes proxy (Paq), $C_{23} / C_{29}$ ratio and modeled $C_{23} / C_{29}$ ratio (Pancost et al., 2002 ) are shown in Fig. 5. Most of the samples showed a maximum at $\mathrm{C}_{23}$ or $\mathrm{C}_{31}$ (Fig. $5 \mathrm{~A}$ ), suggesting a distinct origin of the OM. Only for 3 samples $\left(178 \mathrm{~cm}, 174 \mathrm{~cm}\right.$, and $66 \mathrm{~cm}$ ) was $C_{25}$ the most abundant $n$-alkane, while another 3 samples had maxima at $C_{29}$ $(312 \mathrm{~cm}, 308 \mathrm{~cm}, 294 \mathrm{~cm})$. Considerable oscillations were apparent in the ACL profile, calculated as $\left[\left(C_{i} \times i+C_{i+1} \times(i+1)+C_{i+2} \times(i\right.\right.$ $\left.\left.+2) \ldots+C_{n} \times n\right)\right) /\left(\sum C_{n+1}+C_{n+2}+\ldots+C_{n}\right)$, with $\left.i=13, n=33\right]$, (Fig. 5B), i.e. values varied between the marked minimum at $182 \mathrm{~cm} \mathrm{(23.20)} \mathrm{and} \mathrm{the} \mathrm{maximum} \mathrm{at} 18 \mathrm{~cm}$ (29.85). The oscillations showed good inverse correspondence with the other indices (Paq, $\mathrm{C}_{23} / \mathrm{C}_{31}, \mathrm{C}_{23} / \mathrm{C}_{29}$, and modeled $\mathrm{C}_{23} / \mathrm{C}_{29}$ ).

The Paq values, calculated as $\left(C_{23}+C_{25}\right) /\left(C_{23}+C_{25}+C_{29}+C_{31}\right)$, oscillated between 0.12 at $14 \mathrm{~cm}$ and 0.96 at $182 \mathrm{~cm}$ (Fig. $5 \mathrm{C}$ ), showing a similar profile to the other $n$-alkane ratios, especially the modeled $C_{23} / C_{29}$. The $C_{23} / C_{29}$ ratio also showed several oscillations (Fig. 5D), with values $<1$ at $312-302 \mathrm{~cm}, 296-294 \mathrm{~cm}, 288-$ $274 \mathrm{~cm}, 260-258 \mathrm{~cm}, 224-222 \mathrm{~cm}, 180-174 \mathrm{~cm}, 152-146 \mathrm{~cm}$, $96-94 \mathrm{~cm}, 68-62 \mathrm{~cm}$ and $48-0 \mathrm{~cm}$. Similar oscillations were apparent in both $C_{23} / C_{29}$ and modeled $C_{23} / C_{29}$, expressed as $[-0.0151$ $\left(C_{23} / C_{29}\right)^{4}+0.1144\left(C_{23} / C_{29}\right)^{3}-0.3916\left(C_{23} / C_{29}\right)^{2}+0.8996\left(C_{23}\right)$ $\left.C_{29}\right)-0.0455$ ] (Fig. 5E).

\subsection{2. n-Alkan-2-ones}

The $n$-alkan-2-ones ranged mainly from $C_{17}$ or $C_{19}$ to $C_{33}$ or $C_{35}$, with a strong odd predominance. In almost all the samples, there was a bimodal distribution, maximizing mainly at $C_{19}$ (Fig. $4 \mathrm{C}$ ) or $C_{27}$ (Fig. $4 D$ ); in some samples they centered on $C_{25}$ or $C_{31}$. In general, there was a clear predominance of $C_{19}$ in most of the record (312-94 cm; Fig. 5F). In contrast, in the uppermost $94 \mathrm{~cm}, C_{27}$ was most abundant, with some exceptions where $C_{25}, C_{31}, C_{21}$ and $\mathrm{C}_{19}$ were predominant.

\subsection{3. n-Alkanoic acids}

All samples showed a strong even predominance, with a distribution ranging mainly from $C_{12}$ to $C_{34}$ and maximizing at $C_{24}$ or $C_{26}$ (Fig. 4F) along the profile (Fig. 5G). However, the uppermost $20 \mathrm{~cm}$ showed a maximum at $C_{16}$, with a bimodal distribution (Fig. $4 \mathrm{E}$ ), and at $304 \mathrm{~cm} \mathrm{C}_{20}$ was most abundant.

\subsection{Lipid biomarkers in living plants}

Coinciding with the analysis of living plants in the Roñanzas peat bog by Ortiz et al. (2011), U. europaeus and J. effusus maximized at $C_{29}$ alkane, whereas in Gramineae $C_{31}$ and $C_{27}$ were the most abundant. Mosses exhibited a greater predominance of higher molecular weight $n$-alkanes, mainly $C_{31}$ (3 samples) and $C_{29}$ (Table 2), with the exception of the species of Sphagnum, which maximized at $C_{23}$, coinciding with the results of previous studies (Baas et al., 2000; Nott et al., 2000; Pancost et al., 2002; Nichols et al., 2006; Ortiz et al., 2011; Bush and McInerney, 2013). These findings thus show that the predominant $n$-alkane in most of Sphagnum moss species is $C_{23}$, while in other plants long chain $n$-alkanes are the most abundant.

$n$-Alkan-2-ones were found at significantly lower concentration than $n$-alkanes in living plants (between 4 and 20 times less abundant) and ranged from $C_{23}$ to $C_{31}$, with an odd predominance (Table 3 ). Those in mosses, including Sphagnum spp., maximized at $\mathrm{C}_{27}$ or $\mathrm{C}_{25}$. Gramineae maximized at $\mathrm{C}_{27}$ or $\mathrm{C}_{31}$, Ericaceae species at $C_{27}$ and $C_{29}$ (Ortiz et al., 2011) and $C_{31}$ was the most abundant in $U$. europaeus and J. effusus stems. In contrast, Ortiz et al. (2011) showed that the predominant $n$-alkan-2-one in $U$. europaeus and $J$. effusus stems were $C_{27}$ and $C_{29}$, respectively. These differences may be attributed to seasonal changes in temperature and/or humidity conditions, which affect the lipid distribution, at least of n-alkanes (cf. Bush and McInerney, 2015). In fact, the n-alkan2-one concentrations measured here in these two species were higher than those reported by Ortiz et al. (2011).

Most of the living plants maximized at $C_{24}$ and $C_{26}$ alkanoic acids (Table 4 ), with the exception of $U$. europaeus, in which $C_{22}$ was most abundant. The findings are in agreement with those of Ortiz et al. (2011). Flowers of $J$. effusus and white beak-sedge (Rhynchospora alba) also maximized at $\mathrm{C}_{22}$.

\section{6. $\mathrm{Ca} / \mathrm{Mg}$}

Ca and $\mathrm{Mg}$ concentrations were used to calculate the $\mathrm{Ca} / \mathrm{Mg}$ molar ratio, which showed values $<1$ in the lowest $20 \mathrm{~cm}$ (Fig. 2D), coinciding with gray and light colored silt derived from the weathering of quartzite. After a sharp increase to 6.3 $(295 \mathrm{~cm})$, the values decreased gently to ca. 1.0, although in the upper part of the record $(40 \mathrm{~cm})$ they reached $\mathrm{ca}$. 3.0.

\subsection{Geochemistry of water}

The $\mathrm{pH}$, conductivity, main anions and cations, total carbon, TIC and TOC concentrations are shown in Table 5.

\section{Discussion}

\subsection{Characterization of the mire}

The concentration of TOC is a fundamental proxy for describing OM content of sediments (Meyers, 2003). It reflects the OM that escapes mineralization during sedimentation, and is influenced by both the initial production of biomass and subsequent degree of degradation. The ash content reflects the inorganic material in sediments, and it is usually employed, together with TOC, to determine the characteristics of mires, i.e. the ash content of ombrotrophic peat is generally low, the mineral fraction being supplied exclusively by atmospheric deposition; in contrast, minerotrophic bogs receive extra mineral nutrients from groundwater and mineral soil 
LC-50/52

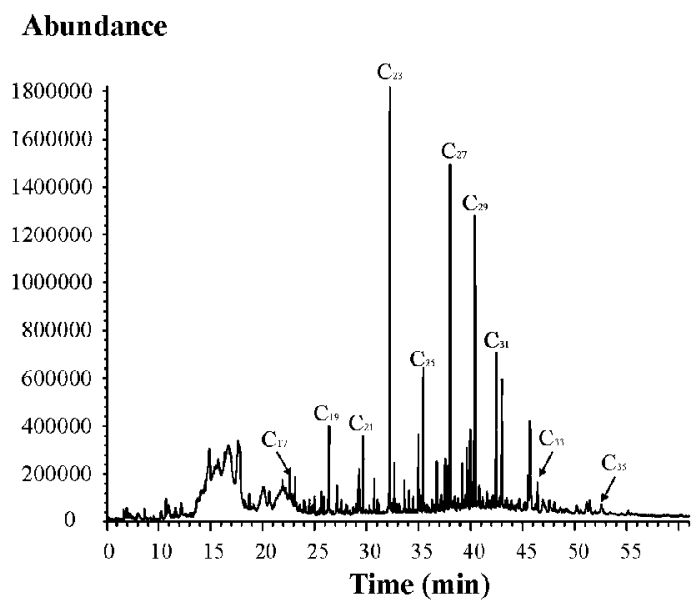

C

Abundance

LC-190/192

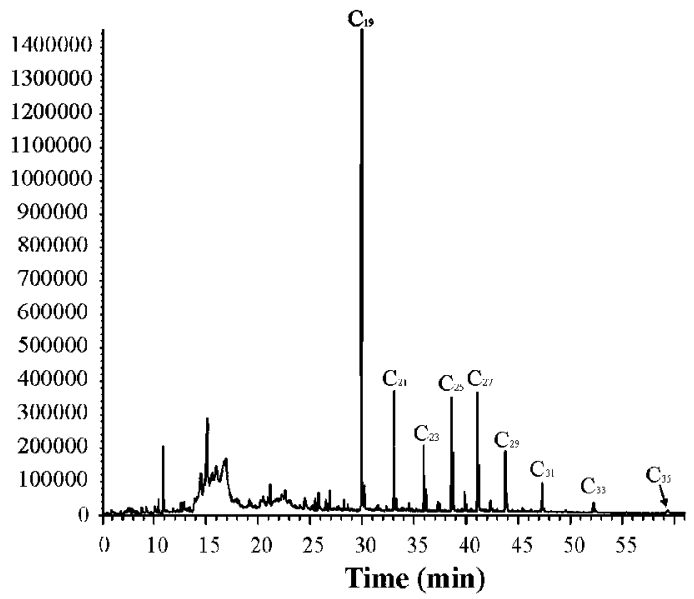

E

Abundance

\section{LC-10/12}

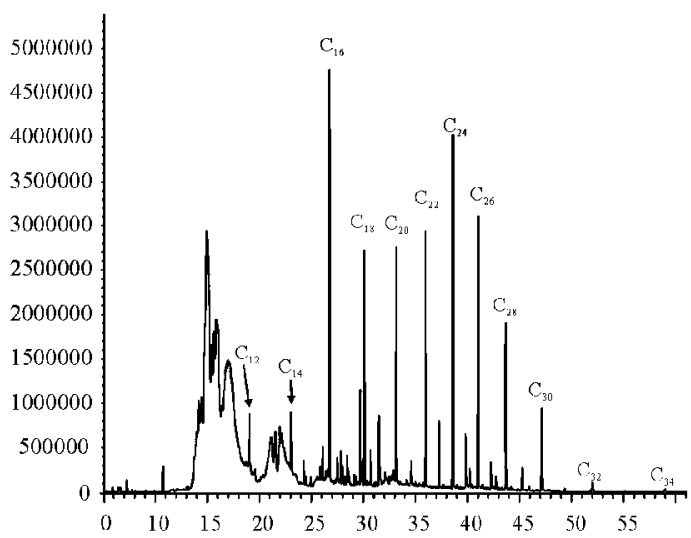

Time (min)
LC-90/92

Abundance

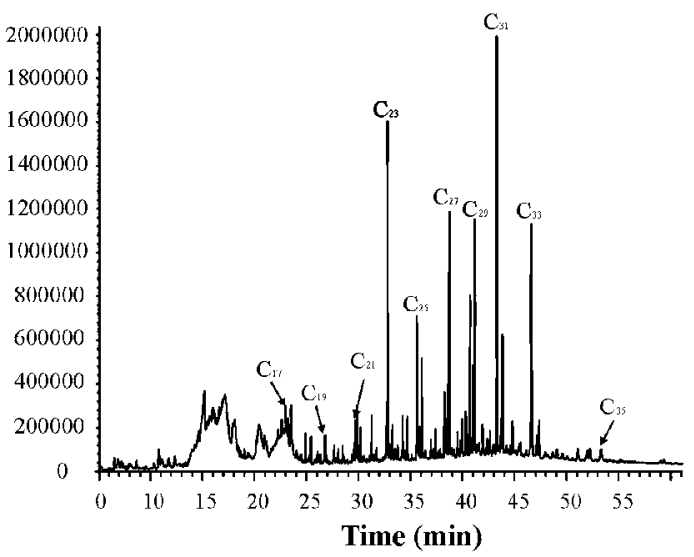

D

Abundance

LC-42/44

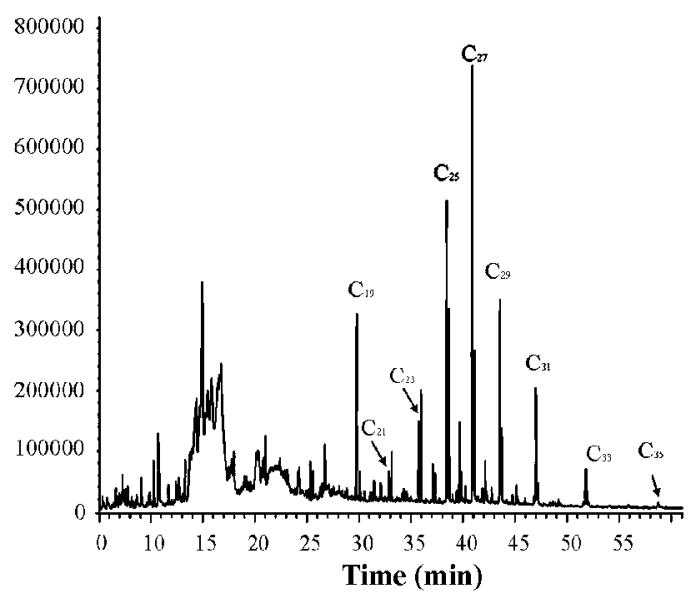

F

Abundance

LC-110/112

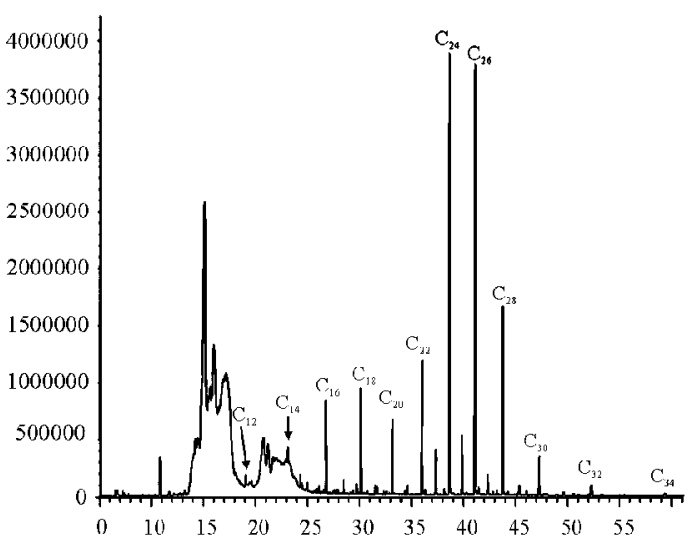

Time (min)

Fig. 4. Typical chromatograms from selected samples in Las Conchas record. (A) and (B) n-alkanes; (C) and (D) n-alkan-2-ones; (E) and (F) n-alkanoic acids. Sample maxima: (A) $C_{23} n$-alkane; (B) $C_{31} n$-alkane; (C) $C_{19} n$-alkan-2-one; (D) bimodal distribution between $C_{27}$ and $C_{19} n$-alkan-2-ones; (E) bimodal distribution between $C_{16}$ and $H M W n$ alkanoic acids; (F) $C_{24} n$-alkanoic acid. $n$-Alkane distributions were obtained from the $m / z 57$ chromatograms (base peak), the $n$-alkan-2-ones from $m / z 59$, and the $n$-alkanoic acids from $m / z 74$. 


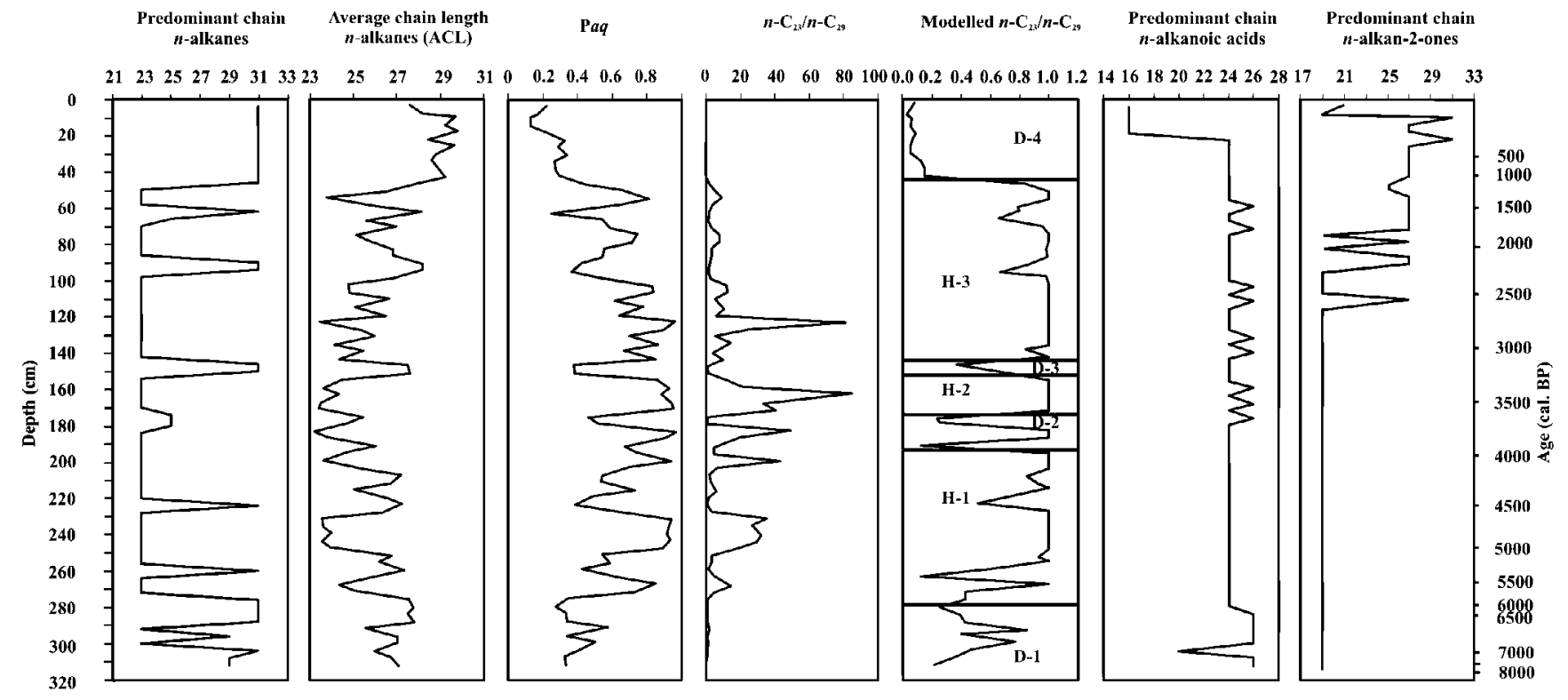

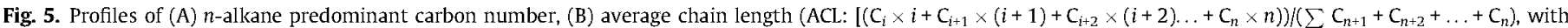

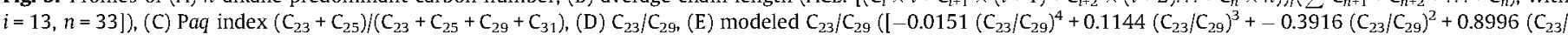
$\left.\left.\mathrm{C}_{29}\right)-0.0455\right]$, (F) predominant $n$-methyl alkan-2-one chain and $(\mathrm{G})$ predominant $n$-alkanoic acid chain. The palaeoenvironmental interpretation is included.

Table 3

Concentration of $n$-alkan-2-ones in plants from Las Conchas mire (highest values in bold).

\begin{tabular}{|c|c|c|c|c|c|c|c|c|c|c|c|c|}
\hline \multirow[t]{2}{*}{ Species } & \multicolumn{12}{|c|}{ Alkan-2-one $C_{\text {no }}(\mu \mathrm{g} / \mathrm{g}$ dry plant matter $)$} \\
\hline & 23 & 24 & 25 & 26 & 27 & 28 & 29 & 30 & 31 & 32 & 33 & Sum \\
\hline Ulex europaeus & 0.00 & 0.00 & 0.18 & 0.17 & 0.69 & 0.16 & 1.31 & 0.27 & 1.34 & 0.00 & 0.00 & 4.12 \\
\hline Juncus effusus & 0.00 & 0.00 & 0.05 & 0.11 & 0.28 & 0.05 & 0.94 & 0.06 & 1.86 & 0.00 & 0.62 & 3.97 \\
\hline Gramineae 1 & 0.00 & 0.00 & 0.29 & 0.42 & 4.37 & 0.58 & 0.86 & 2.34 & 0.54 & 0.00 & 0.63 & 10.02 \\
\hline Gramineae 2 & 0.00 & 0.00 & 0.43 & 0.28 & 0.80 & 0.00 & 1.12 & 0.00 & 0.84 & 0.00 & 0.50 & 3.99 \\
\hline Calliergonella cuspidata & 0.19 & 0.00 & 1.21 & 0.11 & 0.64 & 0.00 & 0.56 & 0.00 & 0.43 & 0.00 & 0.52 & 3.64 \\
\hline Polytrichum commune & 0.41 & 0.12 & 1.12 & 0.70 & 1.07 & 0.27 & 0.64 & 0.14 & 0.37 & 0.00 & 0.15 & 4.99 \\
\hline Campylopus flexuosus & 0.40 & 0.10 & 0.86 & 0.55 & 2.88 & 0.50 & 2.41 & 0.30 & 2.84 & 0.00 & 1.90 & 12.75 \\
\hline Sphagnum denticulatum & 0.65 & 0.26 & 3.82 & 1.06 & 9.43 & 0.49 & 1.57 & 0.16 & 1.08 & 0.00 & 1.25 & 19.77 \\
\hline Aulacomnium palustre & 0.41 & 0.66 & 0.64 & 0.37 & 3.67 & 0.47 & 2.57 & 0.18 & 2.52 & 0.00 & 2.62 & 14.11 \\
\hline Kindbergia praelonga & 0.18 & 0.15 & 0.58 & 0.38 & 1.89 & 0.28 & 1.23 & 0.00 & 1.13 & 0.00 & 0.86 & 6.69 \\
\hline
\end{tabular}

Table 4

Concentration of n-alkanoic acids in plants from Las Conchas mire (highest values in bold).

\begin{tabular}{|c|c|c|c|c|c|c|c|c|c|c|c|c|c|c|c|c|c|c|}
\hline \multirow[t]{2}{*}{ Species } & \multicolumn{17}{|c|}{ Alkanoic acid $C_{\text {no }}(\mu g / g$ dry plant matter $)$} & \multirow[t]{2}{*}{ Sum } \\
\hline & 16 & 17 & 18 & 19 & 20 & 21 & 22 & 23 & 24 & 25 & 26 & 27 & 28 & 29 & 30 & 31 & 32 & \\
\hline Ulex europaeus & 0.54 & 0.06 & 0.37 & 1.33 & 24.41 & 4.74 & 33.75 & 14.73 & 17.32 & 3.83 & 5.64 & 1.94 & 20.26 & 6.21 & 29.50 & 0.84 & 2.00 & 167.66 \\
\hline Juncus effusus & 0.20 & 0.01 & 0.08 & 0.15 & 1.40 & 0.47 & 6.51 & 1.63 & 7.74 & 2.21 & 2.59 & 0.50 & 6.58 & 1.02 & 2.74 & 0.58 & 6.10 & 40.53 \\
\hline Gramineae 1 & 0.59 & 0.02 & 0.17 & 0.21 & 5.77 & 0.82 & 11.17 & 1.96 & 12.68 & 4.28 & 31.05 & 0.59 & 18.35 & 0.47 & 7.86 & 0.17 & 7.21 & 103.47 \\
\hline Gramineae 2 & 1.16 & 0.03 & 0.30 & 2.01 & 7.07 & 2.03 & 25.22 & 6.16 & 25.85 & 8.08 & 15.92 & 2.42 & 17.69 & 0.97 & 6.28 & 0.26 & 2.23 & 125.98 \\
\hline Calliergonella cuspidata & 0.01 & 1.52 & 0.01 & 0.15 & 1.52 & 0.42 & 4.25 & 1.25 & 19.28 & 4.16 & 7.81 & 0.58 & 5.83 & 0.65 & 3.38 & 0.40 & 1.97 & 53.26 \\
\hline Polytrichum commune & 0.01 & 0.40 & 0.01 & 0.75 & 9.25 & 1.56 & 18.13 & 3.91 & 24.40 & 4.02 & 6.86 & 1.06 & 5.45 & 0.70 & 3.73 & 0.20 & 0.97 & 81.50 \\
\hline Campylopus flexuosus & 0.93 & 0.05 & 0.41 & 0.69 & 6.49 & 2.22 & 21.00 & 7.67 & 42.27 & 16.67 & 54.13 & 5.02 & 45.32 & 3.70 & 24.81 & 2.61 & 15.61 & 249.79 \\
\hline Sphagnum denticulatum & 1.07 & 0.10 & 0.44 & 0.12 & 9.46 & 2.21 & 31.47 & 8.93 & 48.76 & 10.17 & 26.39 & 1.57 & 8.56 & 1.55 & 6.77 & 0.83 & 4.20 & 162.93 \\
\hline Aulacomnium palustre & 1.31 & 0.04 & 0.46 & 0.58 & 14.79 & 2.18 & 27.26 & 7.85 & 51.89 & 18.91 & 41.51 & 2.55 & 32.35 & 2.88 & 22.15 & 1.97 & 14.51 & 243.41 \\
\hline Kindbergia praelonga & 1.41 & 0.04 & 0.43 & 0.55 & 9.63 & 1.02 & 9.26 & 3.37 & 21.10 & 9.40 & 12.23 & 1.08 & 14.90 & 1.45 & 15.14 & 0.76 & 7.52 & 109.40 \\
\hline
\end{tabular}

water (Shotyk, 1988, 1996a). In ombrotrophic peat, the ash content is $<5 \%$ by weight (Naucke, 1990; Steinman and Shotyk, 1997; Weiss et al., 2002), typically in the region of $1-3 \%$.

The lower concentration of TOC at the bottom of the record coincided with the increase in detritic sediments (mainly lutite) and ash content $(>10 \%)$. The sudden increase in TOC (from $7-30 \%$ to $55 \%$ ) and decrease in ash content (from $80 \%$ to $<5 \%$ ) at $294 \mathrm{~cm}$ marked a dramatic change in the sedimentary record, with the predominance of peat and the establishment of bog conditions.
Despite the relatively abundant inorganic material in two samples $(190 \mathrm{~cm}, 96 \mathrm{~cm})$, the ash content between $294 \mathrm{~cm}$ and $18 \mathrm{~cm}$ $(<3 \%)$ was within the typical range for ombrotrophic peat bogs (cf. Naucke, 1990), which was confirmed by the TOC values (Fig. 2A). Moreover, the high TOC concentration, together with the scarce variation from $294 \mathrm{~cm}$ to the upper $20 \mathrm{~cm}$ top of the core, and low ash content indicate a slow OM decay rate (Meyers and Ishiwatari, 1993; Meyers and Lallier-Verges, 1999), supporting the idea that the ash content reflects in most part of the profile the 
minerals originally deposited in the mire, with no posterior input or transformation.

However, in the uppermost $20 \mathrm{~cm}$, the ash content increased, reaching values up to $9.6 \%$, while TOC slightly decreased. Elevated concentrations of mineral matter in the surface layers of bogs (Le Roux and Shotyk, 2006) have been attributed to the following: a change in peat accumulation rate (Steinmann and Shotyk, 1997); peat decomposition and humification (Zaccone et al., 2012); variation in the rate of deposition of atmospheric soil dust (Shotyk, 2001; Zaccone et al., 2012) sometimes produced by local human activity, or significant input of volcanic ash (Dugmore and Newton, 1992; Wastegard et al., 2003). Also, higher ash content may indicate a temporary drying of the bog surface in response to local land use practices, such as extensive forest clearing or grazing (Steinmann and Shotyk, 1997).

Also, mires are usually classified as ombrotrophic or minerotrophic on the basis of a comparison of the $\mathrm{Ca} / \mathrm{Mg}$ ratio of the peat with that of local rainwater (Shotyk, 1996b; Steinman and Shotyk, 1997; Weiss et al., 1997). The assumption is that peat with a value lower than, or comparable to, rainwater is ombrotrophic; otherwise, the peat has an additional, non-atmospheric source of $\mathrm{Ca}^{2+}$ and is therefore minerotrophic. In the mire, $\mathrm{Ca} / \mathrm{Mg}$ values (Fig. 2D) were lower than those of rainwater (7.2), which is typical of ombrotrophic bogs, coinciding with the interpretation of the ash content and TOC. In fact, the value (5.2) for water collected from the mire was also $<7.2$. Moreover, runoff water entering the mire from the Cuera Range showed similar values (7.4) to those of rainfall.

\subsection{Paleoenvironmental reconstruction}

The establishment of bog conditions in Las Conchas began ca. $8000 \mathrm{cal}$ yr BP. Some mires in Northern Spain also started to develop at the same age (cf. Martínez-Cortizas et al., 2009; López-Días et al., 2010b, 2013a; Ortiz et al., 2010). Other studies also support high lake water levels during the early to midHolocene, even in the warmer and drier Mediterranean realm of the Iberian Peninsula (Roca and Juliá, 1997; Giralt et al., 1999; Reed et al., 2001). Thus, the end of the Last Glacial Maximum (LGM) and start of the Holocene brought about an improvement in climate (warmer and more humid), which favored the formation of mires in Northern Spain (Pontevedra-Pombal et al., 2006). In fact, based on quantitative climate reconstruction from over 500 pollen sites, Davis et al. (2003) indicated that the final disappearance of residual LGM ice in Europe occurred around $7800 \mathrm{cal}$ BP and was followed by stable conditions for the remaining Holocene.

$n$-Alkane profiles are used to distinguish the source of $\mathrm{OM}-\mathrm{al}-$ gal, aquatic or terrigenous-and each sample can be characterized by the predominant $n$-alkane chain.

In mire-forming plants, there are clear differences in the $n$ alkane distribution of Sphagnum species, which are usually linked to more humid conditions, and non-Sphagnum species (Table 2). Coincident with Baas et al. (2000), Nott et al. (2000), Pancost et al. (2002), Nichols et al. (2006) and Ortiz et al. (2011), the predominant $n$-alkane in most Sphagnum moss was $C_{23}$, while in other plants, like in the Gramineae, Ulex, Juncus, Erica and Calluna, $\mathrm{C}_{31}$ was the most abundant. Of note, most mosses, with the exception of $S$. denticulatum, maximized at long chain $n$-alkanes (Table 2). Also, in some Sphagnum species (e.g. S. capillifolium, S. magellanicum, S. cuspidatum), there was a bimodal distribution, with a second maximum at $\mathrm{C}_{31}$ (Baas et al., 2000; Nott et al., 2000; Pancost et al., 2002). Given that the $n$-alkane profiles of Sphagnum (maximizing at $\mathrm{C}_{23}$ ) and other plants (predominance of $\mathrm{C}_{31}$ ) differ, the predominant $n$-alkane chain distribution in Las Conchas record (Fig. 5A) could serve as indicator of changes in vegetation and environmental conditions.

Sometimes, even in Sphagnum-dominated peat, the $n$-alkane distribution may be influenced by other taxa, and the environmental interpretation can be misleading (Schellekens and Buurman, 2011; Andersson et al., 2011). In addition, the $n$-alkane contributions of the various species differs, as observed in the higher abundance of $n$-alkanes in ericoids compared with other peat-forming plants (Pancost et al., 2002; Ortiz et al., 2011; Huang et al., 2012). Moreover, in peat with a relatively low contribution from Sphagnum, some $n$-alkane indices reflect the degree of decomposition rather than climatic conditions (Schellekens and Buurman, 2011). In Las Conchas, the contribution of non-Sphagnum plants seems to be limited, i.e. the predominance of $C_{23}$ alkane (typically derived from Sphagnum) in the record suggested that other species did not make a major contribution to peat. Only in some intervals, especially in the upper $40 \mathrm{~cm}$, did other plants seem to have a greater input to the mire.

The mire showed significant and high correlation coefficient values $(R>0.69$; Table 6$)$ between long chain $n$-alkanes $\left(C_{27}-C_{29}\right.$, $C_{29}-C_{31}, C_{27}-C_{31}$ and $C_{31}-C_{33}$ ), thereby indicating that these compounds had a related origin, mainly from Ericaceae, Gramineae and other plants. However, it cannot be ruled out that this good correspondence might be determined by a superimposed process (e.g. decomposition). In contrast, the correlation coefficients between $C_{23}$ and high molecular weight (HMW) $n$-alkanes $\left(C_{27}\right.$, $C_{29}, C_{31}$ and $\left.C_{33}\right)$ were inverse $(R-0.25)$, indicating a different OM source, mainly Sphagnum.

The predominant $n$-alkane chain record (Fig. 5A) showed a dominance of $\mathrm{C}_{23}$ along the profile, revealing a major abundance of Sphagnum species and humid conditions, with some intervals with $C_{31}$ dominant, especially in the uppermost $40 \mathrm{~cm}$, which is linked to the predominance of other taxa, possibly Gramineae and ericoids. The upper part of the record indicated changes in the last ca. $200 \mathrm{yr}(20 \mathrm{~cm})$, possibly due to anthropogenic influence (change in the use of soil, deforestation, construction of a trail). In fact, at present, the mire is a meadow devoted to livestock grazing, grasses being very abundant.

A similar but more accurate interpretation can be made by considering other $n$-alkane indices: $A C L, P a q$ index, $C_{23} / C_{29}$ ratio and modeled $C_{23} / C_{29} n$-alkane ratio. The latter proxy is perhaps the one in which transitions are most clearly defined. The use of the

Table 5

General characterization of water samples (all values are an average of 3 measurements on distinct replicas; Samples locations in Fig. 1).

\begin{tabular}{|c|c|c|c|c|c|c|}
\hline & Rainwater (1) & Spring (2) & Tornu River (3) & Contact Cuera Range/Las Conchas (4) & Las Conchas (5) & Roñanzas (6) \\
\hline $\mathrm{pH}$ & 6.7 & 7.2 & 7.4 & 6.3 & 5.7 & 4.5 \\
\hline Conductivity $(\mu \mathrm{S} / \mathrm{cm})$ & 28 & 245 & 311 & 109 & 59 & 80 \\
\hline $\mathrm{Ca}^{2+}(\mathrm{mg} / \mathrm{l})$ & 3.14 & 45.64 & 61.63 & 11.55 & 7.63 & 0.51 \\
\hline $\mathrm{Mg}^{2+}(\mathrm{mg} / \mathrm{l})$ & 0.25 & 1.85 & 0.60 & 0.89 & 0.85 & 1.05 \\
\hline$(\mathrm{Ca} / \mathrm{Mg})_{\text {molar }}$ & 7.22 & 14.18 & 59.06 & 7.46 & 5.16 & 0.28 \\
\hline $\mathrm{HCO}_{3}^{-}(\mathrm{mg} / 1)$ & 3.60 & 149.50 & 198.00 & 25.90 & 8.90 & 4.33 \\
\hline $\mathrm{TC}(\mathrm{mg} / \mathrm{l})$ & 9.42 & 31.5 & 41.9 & 45.5 & 28.3 & 46.40 \\
\hline TIC (mg/l) & 1.19 & 29.8 & 37.8 & 7.0 & 4.8 & - \\
\hline TOC (mg/l) & 8.23 & 1.70 & 4.10 & 38.60 & 23.60 & 46.40 \\
\hline
\end{tabular}


Table 6

Correlation coefficients between $n$-alkanes in samples from Las Conchas mire ( $P$, significant level).

\begin{tabular}{|c|c|c|c|c|c|c|c|}
\hline n-Alkane & $C_{21}$ & $\mathrm{C}_{23}$ & $\mathrm{C}_{25}$ & $\mathrm{C}_{27}$ & $C_{29}$ & $C_{31}$ & $\mathrm{C}_{33}$ \\
\hline$C_{19}$ & $\begin{array}{l}0.6846 \\
P<0.001\end{array}$ & $\begin{array}{l}0.5328 \\
P<0.001\end{array}$ & $\begin{array}{l}0.1665 \\
P=0.145\end{array}$ & $\begin{array}{l}-0.1052 \\
P=0.359\end{array}$ & $\begin{array}{l}0.0396 \\
P=0.731\end{array}$ & $\begin{array}{l}-0.0619 \\
P=0.590\end{array}$ & $\begin{array}{l}-0.0658 \\
P=0.567\end{array}$ \\
\hline$C_{21}$ & & $\begin{array}{l}0.3683 \\
P=0.001\end{array}$ & $\begin{array}{l}0.3705 \\
P=0.001\end{array}$ & $\begin{array}{l}0.1240 \\
P=0.279\end{array}$ & $\begin{array}{l}0.2945 \\
P=0.009\end{array}$ & $\begin{array}{l}0.0626 \\
P=0.586\end{array}$ & $\begin{array}{l}0.0631 \\
P=0.583\end{array}$ \\
\hline$C_{23}$ & & & $\begin{array}{l}0.1327 \\
P=0.247\end{array}$ & $\begin{array}{l}-0.2300 \\
P=0.043\end{array}$ & $\begin{array}{l}-0.2234 \\
P=0.049\end{array}$ & $\begin{array}{l}-0.2690 \\
P=0.017\end{array}$ & $\begin{array}{l}-0.2479 \\
P=0.029\end{array}$ \\
\hline $\mathrm{C}_{25}$ & & & & $\begin{array}{l}0.6927 \\
P<0.001\end{array}$ & $\begin{array}{l}0.5428 \\
P<0.001\end{array}$ & $\begin{array}{l}0.5712 \\
P<0.001\end{array}$ & $\begin{array}{l}0.6438 \\
P<0.001\end{array}$ \\
\hline$C_{27}$ & & & & & $\begin{array}{l}0.7894 \\
P<0.001\end{array}$ & $\begin{array}{l}0.6904 \\
P<0.001\end{array}$ & $\begin{array}{l}0.6821 \\
P<0.001\end{array}$ \\
\hline$C_{29}$ & & & & & & $\begin{array}{l}0.7075 \\
P<0.001\end{array}$ & $\begin{array}{l}0.5550 \\
P<0.001\end{array}$ \\
\hline$C_{31}$ & & & & & & & $\begin{array}{l}0.8410 \\
P<0.001\end{array}$ \\
\hline
\end{tabular}

$\mathrm{ACL}$ has been proposed as a better proxy for discriminating between the predominance of low MW (LMW) vs. HMW $n$-alkanes (Pancost et al., 2002).

Ficken et al. (2000) proposed the Paq index to determine the input of submerged/floating aquatic macrophytes, which maximize at $C_{23}$ and $C_{25}$, relative to the emergent and terrestrial plant input to lake sediments. Given that the ratio compares the abundance of medium chain $n$-alkanes with the sum of the abundance of medium and long chain $n$-alkanes and that Sphagnum species have $n$-alkane profiles similar to those of aquatic macrophytes (cf. Ficken et al., 2000; Baas et al., 2000; Nott et al., 2000; Pancost et al., 2002; Nichols et al., 2006), Nichols et al. (2006) proposed its use for the determination of the relative abundance of Sphagnum vs. other bog-forming plants.

Nichols et al. (2006) used the $C_{23} / C_{29} n$-alkane ratio to discriminate between major Sphagnum input vs. other plant inputs, as $C_{29}$ is relatively scarce in Sphagnum but abundant in other species. However, as the ratio does not represent two pure end members, the authors proposed a correction based on the mean $n$-alkane distribution of Sphagnum and non-Sphagnum plants in order to reduce interference. The modeled $C_{23} / C_{29} n$-alkane ratio is indicative of the abundance of Sphagnum relative to that of other plants in peat.

Good inverse correspondence was observed between ACL and Paq, $C_{23} / C_{29}$, and modeled $C_{23} / C_{29}$ (Fig. $5 E$ ), and it was possible to identify distinct Sphagnum vs. other plant inputs and thus paleoenvironmental episodes related to alternating drier (D) and more humid $(\mathrm{H})$ conditions in the record (cf. Nott et al., 2000; Pancost et al., 2002; McClymont et al., 2005; Nichols et al., 2006; Ortiz et al., 2010). Castro et al. (2015) described the ecological characteristics of typical peat-forming plants in NW Spain and identified 3 groups of taxa on the basis of their behavior: (a) species of waterlogged ecotopes (Sphagnum spp., including mainly S. denticulatum, and one species of sedge and another of rushes), (b) species adapted to fluctuating water table level but with a preference for damp habitats (many Sphagnum, some sedges and grasses) and (c) indicator species of drier heath conditions (mainly Ericaceae).

Thus, three main episodes, interpreted as periods of increasing humidity because of predominance of $C_{23}$, linked to the increase in Sphagnum-like species (mainly $S$. denticulatum), were established $(270-190 \mathrm{~cm}$ [6000-4000 cal yr BP], $175-150 \mathrm{~cm}$ [37003300 cal yr BP], $145-40 \mathrm{~cm}$ [ $3200-1000$ cal yr BP]). These alternated with another 4 dominated by $\mathrm{C}_{31}$, which were associated with the development of other plants $(316-270 \mathrm{~cm}, 190-175 \mathrm{~cm}$, $150-145 \mathrm{~cm}$, and $40-0 \mathrm{~cm}$ ) and would indicate drier conditions.

\subsubsection{Geomorphological control}

Surprisingly, humid conditions were common in most of the record, covering mainly from 6000 cal yr BP to ca. 1000 cal yr BP, although with some drier episodes and with the exception of the last $1000 \mathrm{yr}$. This interpretation does not correlate with the paleoenvironmental conditions interpreted for the neighboring Roñanzas peat bog (Ortiz et al., 2010; López-Días et al., 2013a), located only $3 \mathrm{~km}$ west of Las Conchas.

In our view, the geomorphological characteristics of Las Conchas mire arose from a continuous input of water from the Cuera Range, even during drier periods. In fact, there is evidence of surface runoff in the mire (Fig. 1): some streams begin at the hinge of the steep slope of the Cuera Range with the flat surface of the mire. In contrast, the Roñanzas peat bog is separated from the Cuera Range by a steep valley (Fig. 1) and rainfall is therefore the sole source of water for that mire.

Despite the continuous input of water derived not only from rainfall but from the Cuera Range, no significant modification in ash content or TOC occurred along Las Conchas record. This observation can be explained by the fact that water comes from superficial runoff and an epikarst, with short residence time and therefore does not become enriched in dissolved ions, which would have precipitated in the mire.

This hypothesis was confirmed by the hydrochemistry of rainwater, groundwater from the Cuera Range aquifer and water from Tornu river, which passes through carboniferous calcareous formations, Las Conchas mire and Roñanzas peat bog (Table 5). It seems that groundwater from the Cuera Range does not feed Las Conchas, as it showed higher concentrations than water from the mire, the lower TC and TIC values for the latter being particularly notable. In contrast, runoff water from the contact of the Cuera Range and Las Conchas mire showed similar concentrations to those of the mire.

Furthermore, hydrochemistry differed between Las Conchas mire and Roñanzas ombrotrophic bog, in spite of both being located over quartzite of the same formation (Fig. 1), i.e. inorganic carbon was present in Las Conchas water, but was absent from Roñanzas; concordantly, $\mathrm{Ca}$ and $\mathrm{HCO}_{3}^{-}$were higher in the former mire, thereby indicating input of water from runoff, in addition to rainfall. However, the total concentration of ions was low and did not make a significant contribution to the mineral content of Las Conchas record.

On the whole, we consider that Las Conchas mire cannot be considered an ombrotrophic bog sensu stricto (as the ash content, TOC and $\mathrm{Ca} / \mathrm{Mg}$ values would suggest), because water input does not derive exclusively from rainfall, in spite of the low mineral content along the record.

\subsection{Degradation of $O M$}

The loss and degradation of OM is discussed on the basis of $n$ alkanoic acids and n-alkan-2-ones concentration and atomic $C / N$ values. 


\subsection{1. n-Alkanoic acids}

Almost all samples from 312 to $20 \mathrm{~cm}$ peaked at $C_{24}$ and $C_{26}$ (Fig. 5G). Given that $C_{24}$ or $C_{26}$ predominates in Sphagnum species (Baas et al., 2000; Pancost et al., 2002) and that the $C_{24}$ alkanoic acid is also the most abundant homolog in other plants (Table 4), such as heather, rush, sedge and other mosses (Pancost et al., 2002; Ortiz et al., 2011), we cannot draw any conclusion about the origin of these compounds on the basis of the predominant $n$-alkanoic acid chain log.

The predominance of $C_{16}$ in the uppermost $20 \mathrm{~cm}$, in which $C_{31}$ was the most abundant $n$-alkane, might be attributable to microbial synthesis of secondary FAs from primary OM, leading to the production of short chain homologs (cf. Kawamura et al., 1987). In fact, a bimodal distribution was observed for these samples, thereby indicating a certain degree of degradation. According to Zheng et al. (2007) climate can influence the $n$-alkanoic acid signal, as microbial activity increases during warm and wet periods, while under a cold and dry climate microbial degradation and diagenesis of OM are slowed (Kuder and Kruge, 1998). In the upper $20 \mathrm{~cm}$ (ca. last $200 \mathrm{yr}$ ), LMW $n$-alkanoic acids prevailed, coinciding with global warming that started in the second half of the 19th century (Jones et al., 2001, 2009). However, if climate was the main driving force of the concentration of LMW n-alkanoic acids, this would have been reflected in other parts of the profile, since important paleoenvironmental changes have been recorded during the last $8000 \mathrm{cal} y \mathrm{r}$ in the northern Iberian Peninsula (cf. MartínezCortizas et al., 1999, 2009; Ortiz et al., 2010; López-Días et al., $2013 \mathrm{~b}$ ). This was not the case as the predominant $n$-alkanoic acid chain did not show significant variation. The acrotelm-catotelm boundary is located at this depth and may support a richer bacterial community grazing on OM during the more oxidizing periods. Changes in land use as a result of livestock farming and deforestation, which were particularly important in the 19th and 20th centuries in the region (Suárez Antuña et al., 2005), and the construction of a trail may have favored recent drainage of the bog, permitting oxidation of OM. In fact, at present, Las Conchas mire is a meadow in which grass is very abundant, thus producing a predominance of $\mathrm{C}_{31}$ alkane in the upper part of the record. Likewise, the decrease in TOC at the top of the record might be attributable to carbon loss linked to the oxidation of OM (Sternberg et al., 2007). However, abundant livestock that grazes on the mire may have also influenced this parameter, together with the increase in TN in this part of the record. Furthermore, the ash content increased from around $2.5 \%$ to $9.6 \%$ in the upper $20 \mathrm{~cm}$. All these features may contribute to the slowing down of peat development in the last $20 \mathrm{~cm}$, which may also cause this part of the record to be seasonally exposed, thereby subjecting $\mathrm{OM}$ to greater degradation.

Given that $n$-alkanoic acids are more sensitive to alteration and degradation than $n$-alkanes (cf. Meyers and Ishiwatari, 1993) and that we did not observe parallel changes in the $n$-alkane profiles, we deduced that no significant degradation of $n$-alkanoic acids occurred from the bottom of the record to $20 \mathrm{~cm}$.

\subsection{2. n-Alkan-2-ones}

$n$-Alkan-2-ones provide information about OM sources and its preservation in sediments. HMW n-alkan-2-ones between $C_{23}$ and $C_{31}$ are present in all species of Sphagnum, maximizing at $\mathrm{C}_{27}$ (Morrison and Bick, 1967; Baas et al., 2000; Nichols and Huang, 2007; Ortiz et al., 2011). Although these compounds have been cited only in Sphagnum moss, here (Table 3) and previously (Ortiz et al., 2011), we observed other peat forming plants with $n$-alkan-2-ones peaking at $C_{25}, C_{27}, C_{29}$ and $C_{31}$.

However, according to Amblès et al. (1993), Jansen and Nierop (2009) and Ortiz et al. (2011), direct input of $n$-alkan-2-ones from plants is not the dominant contributor to the distributions in certain soils and peatlands. Thus, long chain alkan-2-ones have other possible sources, including microbial oxidation of the corresponding $n$-alkanes (Amblès et al., 1993; van Bergen et al., 1998) and microbial $\beta$-oxidation and decarboxylation of FAs (Püttmann and Bracke, 1995), especially in peatlands, in which microbial activity can be significant (cf. Lehtonen and Ketola, 1990; Zheng et al., 2007). On the basis of the higher $\delta^{13} \mathrm{C}$ values of $n$-alkane-2-ones compared with $n$-alkanes, López-Días et al. (2013b) suggested that bacterial activity could be a greater contributor of alkan-2-ones to peat than the other two sources. In fact, some taxa of bacteria produce alkan-2-ones via the metabolism of FAs (Lawrence, 1966), fatty alcohols (Hou et al., 1983) and alkanes (Forney and Markovets, 1971). Many taxa of fungi, which also produce alkan2-ones via an abortive $\beta$ oxidation sequence (Forney and Markovets, 1971), could be responsible for the predominance of $C_{19}$. Recently, Schellekens et al. (2015c) indicated that $C_{19}$ was the dominant homologue in the moss Hypnum cupressiforme, suggesting that non-Sphagnum moss could be the source of this compound.

In Las Conchas, there was a predominance of $C_{19}$, from the bottom to $94 \mathrm{~cm}$, whereas in the upper part of the record, alkan-2ones maximized mainly at $\mathrm{C}_{27}$, although with a bimodal distribution, with the other maximum centered around $\mathrm{C}_{19}$ (Fig. 5F).

Morrison and Bick (1967) found alkan-2-ones in peat extending over the $C_{17}-C_{35}$ range, with $C_{25}$ and $C_{27}$ the most abundant. According to Xie et al. (2004), $n$-alkan-2-ones in the peat of Bolton Fell Moss (Northern England) range from $C_{25}$ to $C_{35}$, with a maximum at either $C_{29}$ or $C_{31}$. Moreover, $C_{23}$ has been reported to be the most abundant alkan-2-one in Zoigê-Hongyuan peat bog in West China (Zheng et al., 2007). A similar predominance of LMW alkan-2-ones as that found in the mire has been reported in other Asturian mires (López-Días et al., 2010a; Arboleya, 2011; LópezDías et al., 2013a; Ortiz et al., 2010), including the nearby Roñanzas peat bog (only $1 \mathrm{~km}$ from Las Conchas), in the region of Galicia (Schellekens et al., 2011), the Hani peat bog in northeastern China (Zheng et al., 2011) and mires in Sweden (Lehtonen and Ketola, 1990 ), in which the shorter chain $C_{17}-C_{23}$ homologs greatly increased in abundance with increasing humification.

The $n$-alkane and $n$-alkanoic acid distributions differed from those of $n$-alkane-2-ones. Accordingly, this observation does not support the predominant origin from $n$-alkane oxidation or from microbial $\beta$-oxidation and decarboxylation of FAs. Bacteria could therefore be the main source of alkan-2-ones, at least between 312 and $94 \mathrm{~cm}$, as López-Días et al. (2013b) inferred for the neighboring Roñanzas mire based on stable carbon isotope measurements of peat $n$-alkan-2-ones. Furthermore, although the contribution from $H$. cupressiforme moss to $C_{19}$ homolog to peat (Schellekens et al., 2015c) cannot be totally ruled out, in our view this was unlikely to occur as this species was not observed in Las Conchas. Moreover, OM appeared to be dominated by Sphagnum, as inferred from the $n$-alkane distribution.

Despite being significant, bacterial activity is not expected to be the main source of alkan-2-ones in the upper $94 \mathrm{~cm}$, as $C_{27}$ was the most abundant $n$-alkane-2-one, with samples maximizing also at $C_{25}, C_{31}$ and $C_{21}$. This composition could be attributed to Sphagnum-rich horizons or other kinds of plants (Table 3; cf. Ortiz et al., 2011) and/or the microbial oxidation of $n$-alkanes (cf. Amblès et al., 1993; van Bergen et al., 1998).

\subsection{3. $C / N$}

$C / N$ is an indicator of the type of OM input since $N$ is found mainly in proteins (Müller and Mathesius, 1999). Bacteria typically have lower atomic $C / N$ values (around 4.2 and 4.1 ; Bordovskiy, $1965)$ than vascular land plants $(\geqslant 20$; Ertel and Hedges, 1985; Hedges et al., 1986; Meyers, 1994), which are protein-poor $(1-10 \%)$ and cellulose-rich. Generally, the content of TN is low in Sphagnum spp. (0.5\%) and higher in vascular plants $(5 \%$; Crum, 
1988 ). This leads to higher atomic $C / N$ values $(>50)$ in Sphagnum spp. than in vascular plants (10-40) (Aerts et al., 1999; Hornibrook et al., 2000; Biester et al., 2003; Schellekens et al., $2015 a$ ). However, the $C / N$ values of the same plant species can vary between sites, being prominent for Sphagnum (Schellekens et al., 2015a). Such prominence can be explained by differences in $\mathrm{N}$ deposition, because living Sphagnum assimilates $\mathrm{N}$ from the atmosphere (Rydin and Clymo, 1989; Aerts et al., 2001; Heijmans et al., 2002), whereas vascular plants require $\mathrm{N}$ from the subsoil (Malmer et al., 2003).

$C / N$ is also a proxy for degree of mass loss, with lower values indicating greater decomposition as there is a preferential depletion of $C$ vs. $N$ during decomposition (Kuhry and Vitt, 1996; Hornibrook et al., 2000; Malmer and Wallen, 2004). According to Muller et al. (2008), the use of the $C / N$ as a proxy for mass loss is useful for mires, as increasing peat humification and decomposition produce low values. However, the $C / N$ ratio does not always follow the same decomposition pattern, and the original vegetation inputs have been proposed to exert considerable control over this proxy (Yeloff and Mauquoy, 2006; Hansson et al., 2013). In fact, changes in $C / N$ values with depth are highly influenced by plant species (Sphagnum vs. vascular plants), decomposition, and atmospheric deposition.

The $C / N$ ratio in graminoid-dominated peatlands shows a much lesser variation than in Sphagnum-dominated mires, which is explained by the low contribution of Sphagnum to these peats (Schellekens and Buurman, 2011; Schellekens et al., 2015a,b). Thus, the variation of $C / N$ can be strongly influenced by vegetation type.

In this regard, we detected lower atomic $C / N$ values only at the bottom and top of the record (Fig. 2B). This could be attributable to a distinct $\mathrm{OM}$ input in the lowermost $20 \mathrm{~cm}$, in which the lithology (gray and light silt), low TOC values and high ash content indicated that peat forming conditions were not fully established. In fact, the $\mathrm{N}$ content was low in this part.

The main part of the record $(290-20 \mathrm{~cm})$ showed atomic $C / N$ values between 25 and 48, coinciding with those of the graminoid-dominated peat bog of Penido Vello in NW Spain (Schellekens et al., 2015a). On the basis of the atomic $C / N$ values measured in peat-forming plants (Aerts et al., 1999; Hornibrook et al., 2000; Biester et al., 2003; Schellekens et al., 2015a), those of Las Conchas record may indicate a mixed contribution of Sphagnum, vascular plants and probably bacteria to peat, the latter probably being predominant, at least at present. However, similar atomic $C / N$ values were also observed in the neighboring Sphagnum-dominated Roñanzas peat bog and other mires in Asturias (López-Días et al., 2013a) and the Netherlands (cf. Verhoeven, 1992). Moreover, a greater contribution of Sphagnum was inferred from the $n$-alkane indices along the record. This can be explained because $C / N$ values are affected by aerobic decomposition, and a small increase in vascular plants may strongly influence variation of the $C / N$ ratio (Schellekens et al., 2015a). Furthermore, although vascular plants are more easily degraded, a mass loss greater than 30\% during the first stage of decay has been reported for Sphagnum litter (Asada et al., 2005). In fact, Schellekens et al. (2015a) observed a decrease of between $30 \%$ and $50 \%$ in $C / N$ values in Sphagnum peat. This observation thus confirms the rapid degradation of Sphagnum polyphenols under aerobic conditions, with a preferential anaerobic decay of polysaccharides. In vascular plants, although the rates of polyphenol and polysaccharide degradation differ, they also contribute to the $C / N$ values of peat.

In the uppermost $20 \mathrm{~cm}$, lower atomic $C / N$ values showed good correspondence with the predominance of short chain $n$-alkanoic acids, thereby indicating a certain degree of microbial activity and peat decomposition. TOC values were lower than in the rest of the record, whereas TN reached the highest values at this depth. According to Kuhry and Vitt (1996), Hornibrook et al. (2000),
Sternberg et al. (2007) and Schellekens et al. (2015a), among others, lower TOC values in the acrotelm reflects the loss of organic compounds during initial decay. In contrast, high values of $\mathrm{N}$ in the upper part of the core probably reflect the rapid recycling of this nutrient by plants in the aerobic layer (cf. Heijmans et al., 2002; Schellekens et al., 2015b). Moreover, livestock may contribute to a higher input of $\mathrm{N}$.

Therefore, atomic $C / N$ values can be indicative of mixed input of vegetation and degree of OM degradation.

\section{Conclusions}

Inorganic and organic geochemical proxies provide useful information for reconstructing paleoenvironmental conditions in mires; however, their interpretation can be influenced by geomorphology, which in some cases may arise from a continuous input of water, even during drier periods.

The profile of $n$-alkanoic acids in the record of Las Conchas mire indicated good preservation of OM, with the exception of the uppermost $20 \mathrm{~cm}$, in which microbial activity and/or oxidation produced a dominance of short chain homologs.n-Alkan-2-ones would indicate bacterial influence from the bottom to $94 \mathrm{~cm}$, whereas in the upper part of the record their distribution can be attributed mainly to plant input and/or the microbial oxidation of $n$-alkanes.

The development of bog conditions in Las Conchas mire occurred in the bottom $20 \mathrm{~cm}$ of the profile, where the ash content decreased from $80 \%$ to $<5 \%$ and TOC increased from $7 \%$ to $55 \%$. The $n$-alkane proxies (predominant chain, $\mathrm{ACL}, \mathrm{Paq}$ index, $\mathrm{C}_{23} / \mathrm{C}_{29}$, modeled $C_{23} / C_{29}$ ) showed variation, which we interpret in terms of changes in vegetation (Sphagnum-dominated vs. nonSphagnum-dominated phases) along the last $8000 \mathrm{cal}$ yr BP. The initial phase of peat development and the upper part of the profile were characterized by the dominance of $C_{31}$ alkane, whereas $C_{23}$ was the most abundant homolog along most of the record. This observation could be interpreted in terms of humid conditions not linked to paleoclimatic variation, i.e. the Cuera Range produced continuous runoff to the mire, even during drier periods.

In the uppermost $20 \mathrm{~cm}$, the ash content increased and TOC diminished. Furthermore, $C_{31}$ was the predominant alkane in this part of the record, and the ACL reached its highest values, coinciding with very low Paq values and a low $\mathrm{C}_{23} / \mathrm{C}_{29}$ ratio. We propose that these observations indicate significant change in the mire over the last ca. $200 \mathrm{yr}$, namely its drainage and transformation into a meadow.

\section{Acknowledgements}

The study was made possible by funding from the Spanish Inter-Ministry Commission of Science and Technology (CICYT), projects CGL2013-46458-C1-1-R, and CGL2013-46458-C2-2-R. L. D. acknowledges a PICATA postdoctoral fellowship of the UCMUPM, Moncloa Campus of International Excellence (Spain) and a Juan de la Cierva postdoctoral fellowship (MINECO, Spanish Government) and J.U. a FPU fellowship from MEC (Spain). We thank three anonymous reviewers for helpful comments.

\section{Associate Editor-P.A. Meyers}

\section{References}

Aerts, R., Verhoeven, J.T.A., Whigham, D.F., 1999. Plant mediated controls on nutrient cycling in temperate fens and bogs. Ecology 80, 2170-2181.

Aerts, R., Malmer, N., de Caluwe, H., 2001. Nutritional constraints on Sphagnumgrowth and potential decay in northern peatlands. Journal of Ecology 89, 292299. 
Amblès, A., Jambu, P., Jacquesy, J.-C., Parlanti, E., Secouet, B., 1993. Changes in the ketone portion of lipid components during the decomposition of plant debris in a hydromorphic forest-podzol. Soil Science 156, 49-56.

Andersson, R.A., Kuhry, P., Meyers, P., Zebühr, Y., Crill, P., Mörth, M., 2011. Impacts of paleohydrological changes on $n$-alkane biomarker compositions of a Holocene peat sequence in the eastern European Russian Arctic. Organic Geochemistry 42, 1065-1075.

Arboleya, M., 2011. Biomarcadores Moleculares como Indicadores Paleoclimáticos en Turberas Asturianas de Ambiente Submontano. MSc Thesis, University of Oviedo, Spain, $30 \mathrm{pp}$.

Arpino, P., Albrecht, P., Ourisson, G., 1970. Series homologues aliphatics dans un sediment Eocène d'origen lacustre. Comptes Rendus Academie de Science, Series D 270, 1760-1763.

Asada, T., Warner, B., Aravena, R., 2005. Effects of the early stage of decomposition on change in carbon and nitrogen isotopes in Sphagnum litter. Journal of Plant Interactions 1, 229-237.

Baas, M., Pancost, R., van Geel, B., Sinninghe Damsté, J.S., 2000. A comparative study of lipids in Sphagnum species. Organic Geochemistry 31, 535-541.

Biester, H., Martínez-Cortizas, A., Birkenstock, S., Kilian, R., 2003. Historic mercury records in peat bogs. The role of peat decomposition, and mass losses. Environmental Science and Technology 37, 32-39.

Bordovskiy, O.K., 1965. Accumulation and transformation of organic substances in marine sediments. Marine Geology 3, 3-114.

Bush, R.T., Mclnerney, F.A., 2013. Leaf wax $n$-alkane distributions in and across modern plants: implications for paleoecology and chemotaxonomy. Geochimica et Cosmochimica Acta 117, 161-179.

Bush, R.T., McInerney, F.A., 2015. Influence of temperature and $C_{4}$ abundance on $n$ alkane chain length distributions across the central USA. Organic Geochemistry $79,65-73$.

Castro, D., Souto, M., García-Rodeja, E., Pontevedra-Pombal, X., Fraga, M.I., 2015 Climate change records between the mid- and late Holocene in a peat bog from Serra do Xistral (SW Europe) using plant macrofossils and peat humification analyses. Palaeogeography, Palaeoclimatology, Palaeoecology 420, 82-95.

Chaffee, A.L., Hoover, D.S., Johns, R.B., Schweighardt, F.K., 1986. Biological matkers extractable from coal. In: Johns, R.B. (Ed.), Biological Markers in the Sedimentary Record. Elsevier, Amsterdam, pp. 311-345.

Cranwell, P.A., 1974. Monocarboxilic acids in lake sediments: indicators, derived from terrestrial and aquatic biota, of paleoenvironmental trophic levels. Chemical Geology 14, 1-14.

Cranwell, P.A. 1976. Decomposition of aquatic biota and sediment formation: lipid components of 2 blue-green algal species and of detritus resulting from microbial attack. Freshwater Biology 6, 481-488.

Cranwell, P.A., Eglinton, G., Robinson, N., 1987. Lipids of aquatic organisms as potential contributors to lacustrine sediments-II. Organic Geochemistry 11, 513-527.

Crum, H., 1988. A Focus on Peatlands and Peat Mosses. University of Michigan Press, Ann Arbor.

Davis, B.A.S., Brewerb, S., Stevenson, A.C., Guiot, J., Data Contributors, 2003. The temperature of Europe during the Holocene reconstructed from pollen data. Quaternary Science Reviews 22, 1701-1716.

de Leeuw, J.W., 1986. Higher-molecular-weight markers. In: Johns, R.B. (Ed.) Biological Markers in the Sedimentary Record. Elsevier, Amsterdam, pp. 249-260.

Dugmore, A.J., Newton, A.J., 1992. Thin Tephra layers in peat revealed by XRadiography. Journal of Archeological Science 19, 163-170.

Ertel, J.R., Hedges, J.I., 1985. Sources of sedimentary humic substances: vascular plant debris. Geochimica et Cosmochimica Acta 49, 2097-2107.

Esterle, J.S., Ferm, J.C., 1994. Spatial variability in modern tropical peat deposits from Sarawak, Malaysia and Sumatra, Indonesia: analogues for coal. International Journal of Coal Geology 26, 1-4.

Ficken, K.J., Li, B., Swain, D.L., Eglinton, G., 2000. An n-alkane proxy for the sedimentary input of submerged/floating freshwater aquatic macrophytes. Organic Geochemistry 31, 745-749.

Forney, F.W., Markovets, A.J., 1971. The biology of methyl ketones. Journal of Lipid Research 12, 383-395

Giralt, S., Burjachs, F., Roca, J.R., Juliâ, R., 1999. Late Glacial to Early Holocene environmental adjustment in the Mediterranean semi-aridzone of the Salinas playa-lake Alicante, Spain. Journal of Paleolimnology 21, 449-460.

Haddad, R.I., Martens, C.S., Farrington, J.W., 1992. Quantifying early diagenesis of fatty acids in a rapidly accumulating coastal marine sediments. Organic Geochemistry 19, 205-216.

Hansson, S.V., Rydberg, J., Kylander, M., Gallagher, K., Bindler, R., 2013. Evaluating paleoproxies for peat decomposition and their relationship to peat geochemistry. Holocene 23, 1666-1671.

Hedges, J.I., Clark, W.A., Quay, P.D., Richey, J.E., Devl, A.H., De Santos, U., 1986 Compositions and fluxes of particulate organic material in the Amazon River. Limnology and Oceanography 31, 717-738.

Heijmans, M.M.P.D., Klees, H., de Visser, W., Berendse, F., 2002. Effects of increased nitrogen deposition on the distribution of ${ }^{15} \mathrm{~N}$-labeled nitrogen between Sphagnum and vascular plants. Ecosystems 5, 500-508.

Hill, B.M., Siegel, D.I., 1991. Groundwater flow and the metal content of peat Journal of Hydrology 123, 211-224

Ho, E.S., Meyers, P.A., 1994. Variability of early diagenesis in lake sediments: evidence from the sedimentary geolipid record in an isolated tarn. Chemica Geology 112, 309-324

Hornibrook, E.R.C., Longstaffe, F.J., Fyfe, W.S., Bloom, Y., 2000. Carbon-isotope ratios and carbon, nitrogen and sulfur abundances in flora and soil organic matter from a temperate zone bog and marsh. Geochemical Journal 34, 237-245.
Hou, C.T., Patel, R., Laskin, A.I., Barnabe, N., Barist, l., 1983. Production of methyl ketones from secondary alcohols by cell suspensions of $C_{2}$ to $C_{4} n$-alkane-grown bacteria. Applied and Environment Microbiology 46, 178-184.

Huang, X., Xue, J., Zhang, J., Qin, Y., Meyers, P.A., Wang, H., 2012. Effect of different wetness conditions on Sphagnum lipid composition in the Erxianyan peatland, central China. Organic Geochemistry 44, 1-7.

Jaffé, R., Cabrera, A., Hausmann, K., Carvajal-Chitty, H., 1993. On the origin and fate of $n$-alkane-2-ones in freshwater environments. In: Manning, D. (Ed.), Organic Geochemistry: Applications in Energy and the Natural Environment. Manchester University Press, Manchester, pp. 356-359.

Jaffé, R., Elisme, T., Cabrera, A.C., 1996. Organic geochemistry of seasonally flooded rain forest soils: molecular composition and early diagenesis of lipid components. Organic Geochemistry 25, 9-17.

Jansen, B., Nierop, K.G.J., 2009. Methyl ketones in high altitude Ecuadorian Andosols confirm excellent conservation of plant-specific $n$-alkane patterns. Organic Geochemistry 40, 61-69.

Jones, P.D., Osborn, T.J., Briffa, K.R., 2001. The evolution of climate over the last millennium. Science 292, 662-667.

Jones, P.D., Briffa, K.R. Osborn, T.J., Lough, J.M., Ommen, T.D., Vinther, B.M., Luterbacher, J., Wahl, E.R., Zwiers, F.W., Mann, M.E., Schmidt, G.A., Ammann, C. M., Buckley, B.M., Cobb, K.M., Esper, J., Goosse, H., Graham, N., Jansen, E., Kiefer, T., Kull, C., Küttel, M., Mosley-Thompson, E., Overpeck, J.T., Riedwyl, N., Schulz, M., Tudhope, A.W., Villalba, R., Wanner, H., Wolff, E., Xoplaki, E., 2009. Highresolution palaeoclimatology of the last millennium: a review of current status and future prospects. Holocene 19, 3-49.

Kawamura, K., Ishiwataria, R., Ogura, K., 1987. Early diagenesis of organic matter in the water column and sediments: microbial degradation and resynthesis of lipids in Lake Haruna. Organic Geochemistry 11, 251-264.

Kuder, T., Kruge, M.A., 1998. Preservation of biomolecules in sub-fossil plants from raised peat bogs-a potential paleoenvironmental proxy. Organic Geochemistry $29,1355-1368$.

Kuhry, P., Vitt, D.H., 1996. Fossil carbon/nitrogen as a measure of peat decomposition. Ecology 77, 271-317.

Lawrence, R.C., 1966. The metabolism of triglycerides by spores of Penicillium roqueforti. Journal of General Microbiology 46, 65-76.

Le Roux, G., Shotyk, W., 2006. Weathering of inorganic matter in bogs. In: Martini, l. P., Martinez Cortizas, A., Chesworth, W. (Eds.), Peatlands: Evolution and Records of Environmental and Climate Changes. Elsevier, Amsterdam, pp. 197-215.

Lehtonen, K., Ketola, M., 1990. Occurrence of long-chain acyclic methyl ketones in Sphagnum and Carex peats of various degrees of humification. Organic Geochemistry 15, 275-280.

López-Días, V., Borrego, Á.G., Blanco, C.G., Arboleya, M., López-Sáez, J.A., LópezMerino, L., 2010a. Biomarkers in a peat deposit in Northern Spain (Huelga de Bayas, Asturias) as proxy for climate variation. Journal of Chromatography A $1217,3538-3546$

López-Días, V., Borrego, A.G., Blanco, C.G., 2010b. Vertical evolution of petrographic and organic geochemical parameters in Las Dueñas mire (Cantabrian Coast North Spain). International Journal of Coal Geology 84, 179-189.

López-Días, V., Urbanczyk, J., Blanco, C.G., Borrego, A.G., 2013a. Biomarkers as paleoclimate proxies in peatlands in coastal high plains in Asturias, $N$ Spain. International Journal of Coal Geology 116-117, 270-280.

López-Días, V., Blanco, C.G., Bechtel, A., Püttmann, W., Borrego, A.G., 2013 b. Different source of $n$-alkanes and $n$-alkan-2-ones in a $6000 \mathrm{cal}$.yr BP Sphagnumrich temperate peat bog (Roñanzas, N Spain). Organic Geochemistry 57, 7-10.

Malmer, N., Wallen, B., 2004. Input rates, decay losses and accumulation rates of carbon in bogs during the last millennium: internal processes and environmental changes. Holocene 14, 111-118.

Malmer, N., Albinsson, C., Svensson, B.M., Wallén, B., 2003. Interferences between Sphagnum and vascular plants: effects on plant community structure and peat formation. Oikos $100,469-482$.

Martínez Cortizas, A., Pontevedra-Pombal, X., García-Rodeja, E., Nóvoa-Muñoz, J.C. Shotyk, W., 1999. Mercury in a Spanish peat bog: archive of climate change and atmospheric metal deposition. Science 284, 939-942.

Martínez Cortizas, A., Costa-Casais, M., López-Sáez, J.A., 2009. Environmental change in NW Iberia between 7000 and $500 \mathrm{cal}$. BC. Quaternary International $200,77-89$.

Martínez García, E., 1980. Mapa Geológico de España 1:50.000, hoja nº 32 (Llanes). IGME, Madrid.

McClymont, E.L., Avsejs, L.A., Nott, C.J., Roberts, Z.E., Volders, F.D.M., Pancost, R.D. Evershed, R.P., 2005. Reconstructing abrupt climate changes over the European land mass during the late Holocene using biomarker analysis of ombrotrophic peats. Abstract. 22nd International Meeting on Organic Geochemistry, Seville, pp. 173-174.

Meyers, P.A., 1994. Preservation of elemental and isotopic source identification of sedimentary organic matter. Chemical Geology 144, 289-302.

Meyers, P.A., 2003. Applications of organic geochemistry to paleolimnological reconstructions: a summary of examples from the Laurentian Great Lakes. Organic Geochemistry 34, 261-289.

Meyers, P.A., Ishiwatari, R., 1993. Lacustrine organic geochemistry-an overview of indicators of organic matter sources and diagenesis in lake sediments. Organic Geochemistry 20, 867-900.

Meyers, P.A., Lallier-Verges, E. 1999. Lacustrine sedimentary organic matter records of Late Quaternary paleoclimates. Journal of Paleolimnology 21, 345-372.

Moore, T.A., Hilbert, R.E., 1992. Petrographic and anatomical characteristics of plant material from two peat deposits of Holocene and Miocene age, Kalimantan, Indonesia. Review of Palaeobotany and Palynology 72, 199-227. 
Morrison, R.I., Bick, W., 1967. The wax fraction of soils: separation and determination of some components. Journal of the Science of Food and Agriculture 18, 351-355.

Müller, A., Mathesius, U., 1999. The palaeoenvironments of coastal lagoons in the southern Baltic Sea. The application of sedimentary $\mathrm{C}_{\mathrm{or} /} / \mathrm{N}$ ratios as source indicators of organic matter. Palaeogeography, Palaeoclimatology, Palaeoecology $145,1-16$.

Muller, J., Kylander, M.E., Wüst, R.A, Weiss, D.J., Martinez Cortizas, A., LeGrande, N., Jennerjahn, T., Behling, H., Anderson, W.T., Jacobson, G., 2008. Possible evidence for wet Heinrich phases in tropical NE Australia: the Lynch's Crater deposit. Quaternary Science Reviews 27, 468-475.

Naucke, W., 1990. Chemie von Moor und Torf. In: Giittlich, K. (Ed.), Moor und Torfkunde. E. Schweizerbart, Stuttgart, pp. 237-261.

Nichols, J.E., Huang, Y., 2007. $C_{23}-C_{31}$ n-alkan-2-ones are biomarkers for the genus Sphagnum in freshwater peatlands. Organic Geochemistry 38, 1972-1976.

Nichols, J.E., Booth, R.K., Jackson, S.T., Pendall, E.G., Hung, Y., 2006. Paleohydrologic reconstruction based on $n$-alkane distributions in ombotrophic peat. Organic Geochemistry 37, 1505-1513.

Nott, C.J., Xie, S., Avsejs, L.A., Maddy, D., Chambers, F.M., Evershed, R.P., 2000. Nalkane distribution in ombotrophic mires as indicators of vegetation change related to climatic variation. Organic Geochemistry 31, 231-235.

Ortiz, J.E., Gallego, J.L.R., Torres, T., Díaz-Bautista, A., Sierra, C., 2010 Palaeoenvironmental reconstruction of Northern Spain during the last $8000 \mathrm{cal}$ yr BP based on biomarker content of the Roñanzas peat bog (Asturias). Organic Geochemistry 41, 454-466.

Ortiz, J.E., Díaz-Bautista, A., Aldasoro, J.J., Torres, T., Gallego, J.L.R., Moreno, L. Estébanez, B., 2011. $\mathrm{N}$-alkan-2-ones in peat-forming plants from the Roñanzas ombrotrophic bog(Asturias, northern Spain). Organic Geochemistry 42, 586-592.

Pancost, R.D., Baas, M., van Geel, B., Sinninghe Damsté, J.S., 2002. Biomarkers as proxies for plant inputs to peats: an example from a sub-boreal ombotrophic bog. Organic Geochemistry 33, 675-690.

Pontevedra-Pombal, X., Nóvoa-Muñoz, J.C., Garcia-Rodeja, E., Martinez-Cortizas, A. 2006. Mountain mires from Galicia. In: Martini, I.P., Martinez-Cortizas, A. Chesworth, W. (Eds.), Peatlands: Evolution and Records of Environmental and Climate Change. Elsevier, Amsterdam, pp. 85-109.

Püttmann, W., Bracke, R., 1995. Extractable organic compounds in the clay mineral sealing of a waste disposal site. Organic Geochemistry 23, 43-54.

Quénéa, K., Derenne, S., Largeau, C., Rumpel, C., Mariotti, A., 2004. Variation in lipid relative abundance and composition among different particle size fractions of a forestsoil. Organic Geochemistry $35,1355-1370$

Reed, J.M., Stevenson, A.C., Juggins, S., 2001. A multi-proxy record of Holocene climatic change in southwestern Spain: the Laguna Medina, Cadiz. Holocene 11, 707-719.

Reimer, P.J., Bard, E., Bayliss, A., Beck, J.W., Blackwell, P.G., Bronk Ramsey, C., Buck, C. E., Cheng, H., Edwards, R.L., Friedrich, M., Grootes, P.M., Guilderson, T.P., Haflidason, H., Hajdas, I., Hatte, C., Heaton, T.J., Hogg, A.G., Hughen, K.A., Kaiser, K.F. Kromer, B., Manning S.W., Niu, M., Reimer, R.W., Richards, D.A., Scott, E.M., Southon, J.R., Turney, C.S.M., van der Plicht, J., 2013. IntCal13 and MARINE13 radiocatbon age calibration curves 0 and 50000 years cal BP. Radiocarbon 55. http://dx.doi.org/10.2458/azu js rc.55.16947.

Rivas-Martínez, S., Rivas y Sảenz, S., 2015. Worldwide Bioclimatic Classification System. www.globalbioclimatics.org (15.06.15).

Roca, J.R., Julià, R., 1997. Late-Glacial and Holocene lacustrine evolution based on Ostracode assemblages in Southeastern Spain. Geobios 30, 823-830.

Rydin, H., Clymo, R.S., 1989. Transport of carbon and phosphorus about Sphagnum. Proceedings of the Royal Society B: Biological Sciences 237, 63-84

Schellekens, J., Buurman, P., 2011. N-Alkane distributions as palaeoclimatic proxies in ombrotrophic peat: the role of decomposition and dominant vegetation. Geoderma 164, 112-121.

Schellekens, J., Buurman, P., Fraga, I., Martínez-Cortizas, A., 2011. Holocene vegetation and hydrologic changes inferted from molecular vegetation markers in peat, Penido Vello (Galicia, Spain). Palaeogeography, Palaeoclimatology, Palaeoecology 299, 56-69.

Schellekens, J., Bindler, R., Martínez-Cortizas, A., McClymont, E., Abbott, G.D. Biester, H., Pontevedra-Pombal, X., Buurman, P., 2015a. Preferential degradation of polyphenols from Sphagnum: 4-isopropenylphenol as a proxy for past hydrological conditions in Sphagnum-dominated peat. Geochimica et Cosmochimica Acta 150, 74-89.

Schellekens, J., Buurman, P., Kuyper, T.W., Abbott, G.D., Pontevedra-Pombal, X., Martínez-Cortizas, A., 2015b. Influence of source vegetation and redox conditions on lignin-based decomposition proxies in graminoid-dominated ombrotrophic peat (PenidoVello, NW Spain). Geoderma 237-238, 270-282.

Schellekens, J., Bradley, J., Abbott, G.D., Fraga, I., Buurman, P., Pontevedra-Pombal, X., Vidal-Torrado, P., 2015c. The use of plant-specific pyrolysis products as biomarkers in peat deposits. Quaternary Science Reviews 123, 254-264.

Shotyk, W., 1988. Review of the inorganic geochemistry of peats and peatland waters. Earth Science Reviews 25, 95-176.

Shotyk, W., 1996a. Natural and anthropogenic enrichments of As, Cu, Pb, Sb, and Zn in ombrotrophic versus minerotrophic peat bog profiles, Jura Mountains, Switzerland. Water, Air, and Soil Pollution 90, 375-405.

Shotyk, W., 1996b. Peat bog archives of atmospheric metal deposition: geochemical evaluation of peat profiles, natural variations in metal concentrations, and metal enrichment factors. Environmental Reviews 4, 149-183.

Shotyk, W., 2001. Geochemistry of the peat bog at Étang de la Gruère, Jura Mountains, Switzerland, and its record of atmospheric $\mathrm{Pb}$ and lithogenic trace metals ( $\mathrm{Sc}$, Ti, Y, Zr, and REE) since $12,370{ }^{14} \mathrm{C}$ BP. Geochimica et Cosmochimica Acta $65,2337-2360$.

Steinmann, P., Shotyk, W., 1997. Geochemistry, mineralogy, and geochemical mass balance on major elements in two peat bog profiles (Jura Mountains, Switzerland). Chemical Geology 138, 25-53.

Sternberg, L.S.L., Pinzon, M.C., Vendramini, P.F., Anderson, W.T., Hope Jahren, A. Beuning, K., 2007. Oxygen isotope ratios of cellulose-derived phenylglucosazone: an improved paleoclimate indicator of environmental water and relative humidity. Geochimica et Cosmochimica Acta 71, 2463-2473.

Stuiver, M., Reimer, P.J., Reimer, R.W., 2014. CALIB 7.0. (program and documentation). http://calib.qub.ac.uk/calib/ (accessed 10.09.14.).

Suárez Antuña, F., Herrán Alonso, M., Ruiz Fernández, J., 2005. La adaptación de hombre a la montaña. El paisaje de Cabrales (Picos de Europa). Ería 68, $373-$ 389.

Telford, R.J., Heegaard, E., Birks, H.J.B., 2004. The intercept is a poor estimate of a calibrated radiocarbon age. Holocene 14, 296-298.

van Bergen, P.F., Nott, C.J., Bull, I.D., Poulton, P.R., Evershed, R.P., 1998. Organic geochemical studies of soils from the Rothamsted Classical Experiments - IV. Preliminary results from a study of the effect of soil pH on the organic matter decay. Organic Geochemistry 29, 1779-1795.

Verhoeven, J.T.A., 1992. Fens and Bogs in the Netherlands: Vegetation, History Nutrient Dynamics and Conservation. Kluwer Academic Publishers, The Netherlands.

Volkman, J.K., Smith, D.J., Eglinton, G., Forsberg, T.E.V., Corner, E.D.S., 1981. Sterol and fatty acid composition of four marine Haptophycean algae. Journal of the Marine Biological Association 61, 509-527.

Volkman, J.K., Farrington, J.W., Gagosian, R., Wakeham, S.G., 1983. Lipid composition of coastal sediments from the Peru upwelling region. In: Bjorøy, M., Albrecht, P., Cornford., C. (Eds.), Advances in Organic Geochemistry. John Wiley and Sons, New York, pp. 228-240.

Wastegard, S., Hall, V.A., Hannon, G.E., Van den Bogaard, C., Pilcher, J.R. Sigurgeisson, M.A., Hermanns-Audardottir, M., 2003. Rhyolitic tephra horizons in northwestern Europe and Iceland from the $\mathrm{AD} 700 \mathrm{~s}-800 \mathrm{~s}$ : a potential alternative for dating first human impact. The Holocene 13, 277-283.

Weiss, D., Shotyk, W., Cheburkin, A.K., Gloor, M., Reese, S., 1997. Atmospheric lead deposition from 12,400 to ca. 2000 yrs BP in a peat bog profile, Jura Mountains, Switzerland. Water, Air, and Soil Pollution 100, 311-324.

Weiss, D., Shotyk, W., Page, S.E., Rieley, J.O., Reese, S., Martinez- Cortizas, A., 2002 The geochemistry of major and selected trace elements in a forested peat bog Kalimantan, SE-Asia, and its implications for past atmospheric dust deposition. Geochimica et Cosmochimica Acta 66, 2307-2323.

Xie, S., Nott, C.J., Avsejs, L.A., Maddy, D., Chambers, F.M., Evershed, R.P., 2004 Molecular and isotopic stratigraphy in an ombotrophic mire for paleoclimate reconstruction. Geochimica et Cosmochimica Acta 68, 2849-2862.

Yeloff, D., Mauquoy, D., 2006. The influence of vegetation composition on peat humification: implications for palaeoclimatic studies. Boreas 35, 662-673.

Zaccone, C., Miano, T.M., Shotyk, W., 2012. Interpreting the ash trend within ombrotrophic bog profiles: atmospheric dust depositions vs. mineralization processes. The Etang de la Gruère case study. Plant and Soil 353, 1-9.

Zheng, Y., Zhou, W., Meyers, P.A., Xie, S., 2007. Lipid biomarkers in the ZoigeHongyuan peat deposit: indicators of Holocene climate changes in West China Organic Geochemistry 38, 1927-1940

Zheng, Y., Zhou, W., Liu, X., Zhang, C.L., 2011. N-alkan-2-one distribution in a northeastern China peat core spanning the last $16 \mathrm{kyr}$. Organic Geochemistry $42,25-30$. 